Prepared in cooperation with the Jekyll Island Authority

\title{
Hydrologic Conditions, Recharge, and Baseline Water Quality of the Surficial Aquifer System at Jekyll Island, Georgia, 2012-13
}

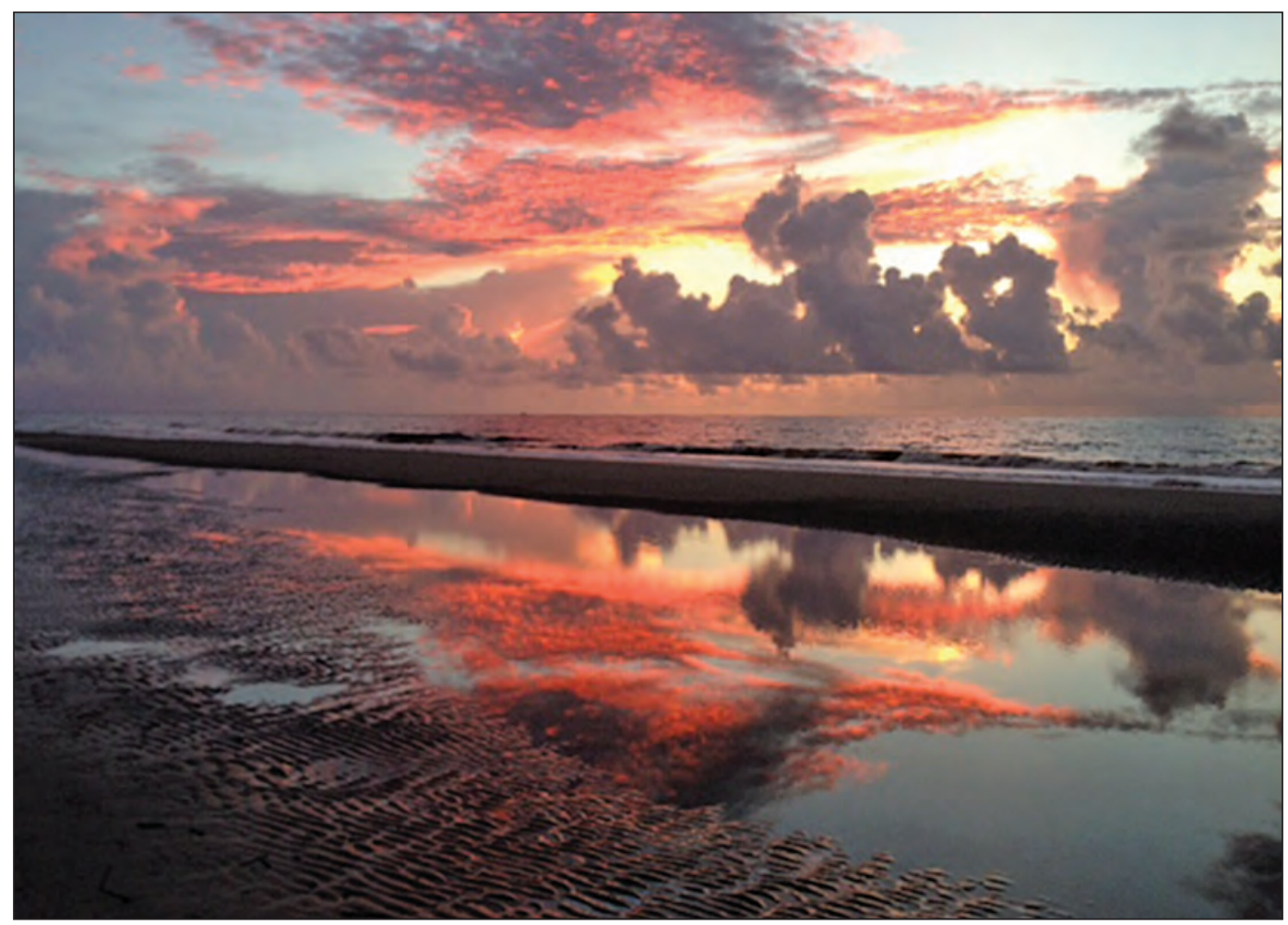

Open-File Report 2016-1017 
Cover. Sunrise over Jekyll Island, Georgia (photograph by John S. Clarke, retired, U.S. Geological Survey). 


\section{Hydrologic Conditions, Recharge, and Baseline Water Quality of the Surficial Aquifer System at Jekyll Island, Georgia, 2012-13}

By Debbie W. Gordon and Lynn J. Torak

Prepared in cooperation with the Jekyll Island Authority

Open-File Report 2016-1017 


\title{
U.S. Department of the Interior SALLY JEWELL, Secretary
}

\section{U.S. Geological Survey Suzette M. Kimball, Director}

\author{
U.S. Geological Survey, Reston, Virginia: 2016
}

For more information on the USGS - the Federal source for science about the Earth, its natural and living resources, natural hazards, and the environment—visit http://www.usgs.gov or call 1-888-ASK-USGS.

For an overview of USGS information products, including maps, imagery, and publications, visit http://www.usgs.gov/pubprod/.

Any use of trade, firm, or product names is for descriptive purposes only and does not imply endorsement by the U.S. Government.

Although this information product, for the most part, is in the public domain, it also may contain copyrighted materials as noted in the text. Permission to reproduce copyrighted items must be secured from the copyright owner.

Suggested citation:

Gordon, D.W., and Torak, L.J., 2016, Hydrologic conditions, recharge, and baseline water quality of the surficial aquifer system at Jekyll Island, Georgia, 2012-13: U.S. Geological Survey Open-File Report 2016-1017, 34 p., http://dx.doi.org/10.3133/ofr20161017.

ISSN 2331-1258 (online) 


\section{Contents}

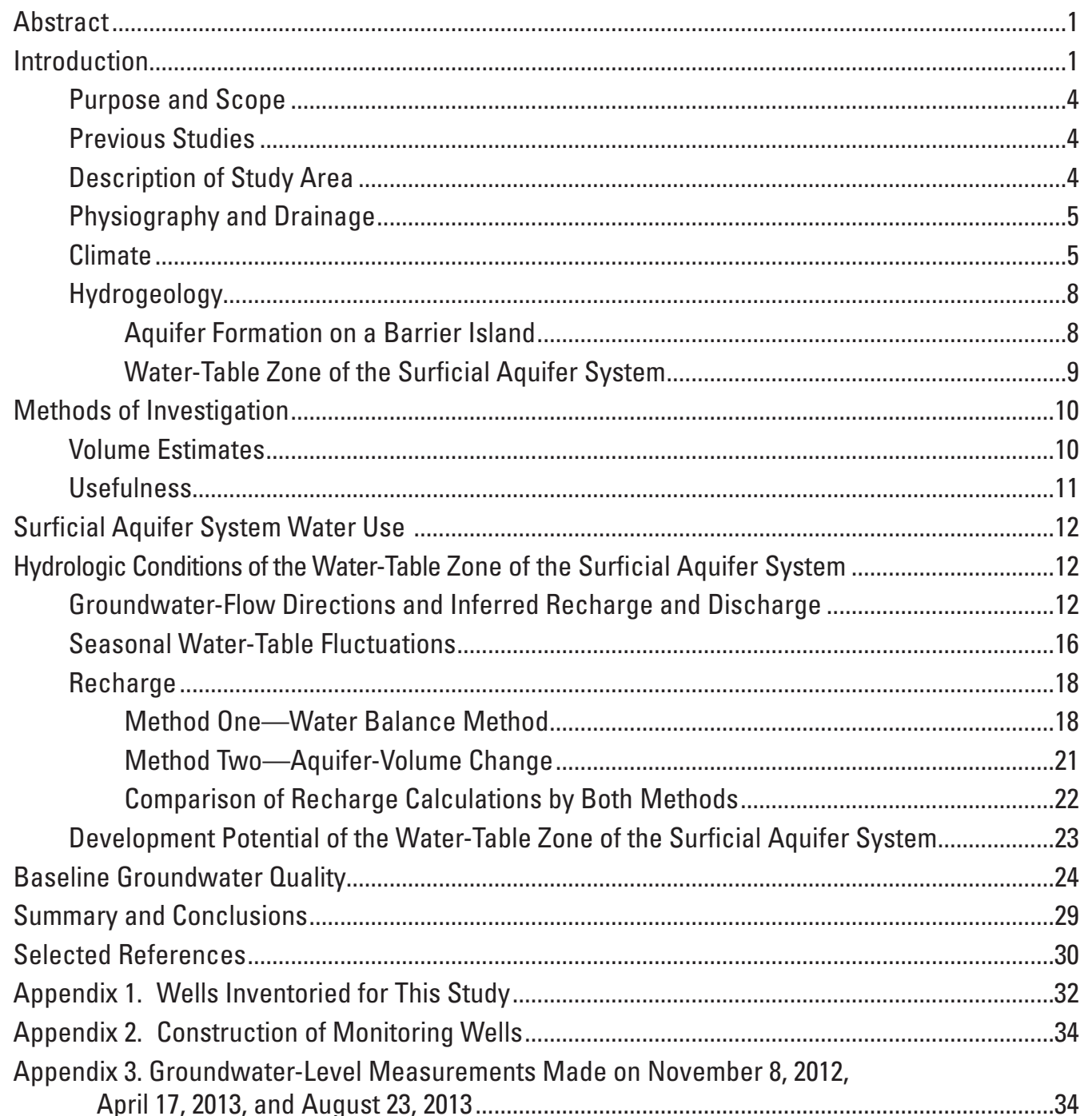




\section{Figures}

1. Maps showing location of Jekyll Island, Coastal Plain, study area; and monitoring wells and gages, Georgia.

2. Map showing land-use-based management units on Jekyll Island, Georgia

3. Map showing light detection and ranging (lidar)-based altitude for central Jekyll Island, Georgia.

4. Graph showing average monthly period of record precipitation for Brunswick, Georgia, and 2013 monthly total precipitation, in inches, at Jekyll Island, Georgia . .7

5. Maps showing sedimentation and erosion features on Jekyll Island, Georgia .8

6. Generalized correlation chart showing the geologic and hydrogeologic units at Jekyll Island composing the lower coastal plain, Georgia ...

7. Graph showing ordinary least squares regression line between specific conductance and chloride concentration for wells completed in the surficial aquifer system, Jekyll Island, Georgia..

8. Maps showing water table for, November 8, 2012; April 17, 2013; and August 23, 2013 on Jekyll Island, Georgia

9. Graphs showing groundwater levels, pond stage, and rainfall for 2013 at Jekyll Island, Georgia

10. Graphs showing monthly total precipitation, potential evapotranspiration, and water balance for the weather station at Brunswick, Georgia,

October 2012-December 2013

11. Graph showing monthly potential maximum recharge for Brunswick, and potential maximum recharge for Jekyll Island using evapotranspiration data from Brunswick, in inches, October 2012-December 2013

12. Graphs showing monthly precipitation at Brunswick and Jekyll Island, Georgia, October 2012-December 2013, and period of record average monthly precipitation at Brunswick, Georgia

13. Maps showing distribution of specific conductance during, November 2012, April 2013, and August 2013 in 26 wells on Jekyll Island, Georgia

1-1. Maps showing location of, and specific conductance measured in, private wells inventoried for this study, Jekyll Island, Georgia, 2012. 


\section{Tables}

1. Period of record average monthly temperature, precipitation, and evapotranspiration for Brunswick, Georgia...

2. Groundwater-quality data for the surficial aquifer system, Jekyll Island, Georgia, August 23, 2013

3. Monthly precipitation, evapotranspiration, and water balance for weather station at Brunswick, Georgia, October 2012-December 2013

4. Monthly potential maximum recharge or discharge for Jekyll Island estimated using precipitation from the Jekyll Island weather station and monthly evapotranspiration from the Brunswick weather station...

5. Average groundwater level difference, aquifer-volume change, and recharge to and discharge from the water-table zone of the surficial aquifer system, Jekyll Island, Georgia, November 8, 2012, to August 23, 2013.

6. Specific conductance values collected from newly constructed wells, Jekyll Island, Georgia, November and December 2012, April and August 2013 


\section{Conversion Factors}

Inch/Pound to International System of Units

\begin{tabular}{|c|c|c|}
\hline Multiply & By & To obtain \\
\hline \multicolumn{3}{|c|}{ Length } \\
\hline inch (in.) & 2.54 & centimeter $(\mathrm{cm})$ \\
\hline inch (in.) & 25.4 & millimeter $(\mathrm{mm})$ \\
\hline foot $(\mathrm{ft})$ & 0.3048 & meter $(\mathrm{m})$ \\
\hline mile (mi) & 1.609 & kilometer (km) \\
\hline \multicolumn{3}{|c|}{ Area } \\
\hline acre & 4,047 & square meter $\left(\mathrm{m}^{2}\right)$ \\
\hline acre & 0.4047 & hectare (ha) \\
\hline square foot $\left(\mathrm{ft}^{2}\right)$ & 929.0 & square centimeter $\left(\mathrm{cm}^{2}\right)$ \\
\hline square foot $\left(\mathrm{ft}^{2}\right)$ & 0.09290 & square meter $\left(\mathrm{m}^{2}\right)$ \\
\hline square mile $\left(\mathrm{mi}^{2}\right)$ & 2.590 & square kilometer $\left(\mathrm{km}^{2}\right)$ \\
\hline \multicolumn{3}{|c|}{ Volume } \\
\hline cubic foot $\left(\mathrm{ft}^{3}\right)$ & 0.02832 & cubic meter $\left(\mathrm{m}^{3}\right)$ \\
\hline million gallons (Mgal) & 3,785 & cubic meter $\left(\mathrm{m}^{3}\right)$ \\
\hline \multicolumn{3}{|c|}{ Recharge } \\
\hline inch per day (in/d) & 2.54 & centimeter per day $(\mathrm{cm} / \mathrm{d})$ \\
\hline inch per year (in/yr) & 2.54 & centimeter per year $(\mathrm{cm} / \mathrm{yr})$ \\
\hline \multicolumn{3}{|c|}{ Flow rate } \\
\hline gallon per minute (gal/min) & 0.06309 & liter per second $(\mathrm{L} / \mathrm{s})$ \\
\hline gallon per day (gal/d) & 0.003785 & cubic meter per day $\left(\mathrm{m}^{3} / \mathrm{d}\right)$ \\
\hline million gallons per day (Mgal/d) & 0.04381 & cubic meter per second $\left(\mathrm{m}^{3} / \mathrm{s}\right)$ \\
\hline \multicolumn{3}{|c|}{ Transmissivity* } \\
\hline foot squared per day $\left(\mathrm{ft}^{2} / \mathrm{d}\right)$ & 0.09290 & meter squared per day $\left(\mathrm{m}^{2} / \mathrm{d}\right)$ \\
\hline
\end{tabular}

Temperature in degrees Celsius $\left({ }^{\circ} \mathrm{C}\right)$ may be converted to degrees Fahrenheit ( $\left.{ }^{\circ} \mathrm{F}\right)$ as

$$
{ }^{\circ} \mathrm{F}=\left(1.8 \times{ }^{\circ} \mathrm{C}\right)+32 .
$$

Temperature in degrees Fahrenheit $\left({ }^{\circ} \mathrm{F}\right)$ may be converted to degrees Celsius $\left({ }^{\circ} \mathrm{C}\right)$ as

$$
{ }^{\circ} \mathrm{C}=\left({ }^{\circ} \mathrm{F}-32\right) / 1.8 \text {. }
$$




\section{Datums}

Vertical coordinate information is referenced to the North American Vertical Datum of 1988 (NAVD 88).

Horizontal coordinate information is referenced to the North American Datum of 1983 (NAD 83).

Altitude, as used in this report, refers to distance above the vertical datum.

\section{Supplemental Information}

*Transmissivity: The standard unit for transmissivity is cubic foot per day per square foot times foot of aquifer thickness $\left[\left(\mathrm{ft}^{3} / \mathrm{d}\right) / \mathrm{ft}^{2}\right] \mathrm{ft}$. In this report, the mathematically reduced form, foot squared per day $\left(\mathrm{ft}^{2} / \mathrm{d}\right)$, is used for convenience.

Specific conductance is given in microsiemens per centimeter at 25 degrees Celsius $(\mu \mathrm{S} / \mathrm{cm}$ at $\left.25^{\circ} \mathrm{C}\right)$.

Concentrations of chemical constituents in water are given in milligrams per liter (mg/L).

\section{Abbreviations}

$\begin{array}{ll}\text { EPA } & \text { U.S. Environmental Protection Agency } \\ \text { ET } & \text { evapotranspiration } \\ \text { GIS } & \text { geographic information system } \\ \text { JIA } & \text { Jekyll Island Authority } \\ \text { NWIS } & \text { National Water Information System } \\ \text { POR } & \text { period of record } \\ \text { PVC } & \text { polyvinyl chloride } \\ \text { SC } & \text { specific conductance } \\ \text { TDS } & \text { total dissolved solids } \\ \text { USGS } & \text { U.S. Geological Survey }\end{array}$




\section{Acknowledgments}

The authors would like to thank the many residents of Jekyll Island who allowed access to their wells for specific conductance measurements. We also thank the Jekyll Island Authority for collecting weekly water-level measurements and providing that and other important data to us. 


\title{
Hydrologic Conditions, Recharge, and Baseline Water Quality of the Surficial Aquifer System at Jekyll Island, Georgia, 2012-13
}

\author{
By Debbie W. Gordon and Lynn J. Torak
}

\begin{abstract}
An increase of groundwater withdrawals from the surficial aquifer system on Jekyll Island, Georgia, prompted an investigation of hydrologic conditions and water quality by the U.S. Geological Survey during October 2012 through December 2013. The study demonstrated the importance of rainfall as the island's main source of recharge to maintain freshwater resources by replenishing the water table from the effects of hydrologic stresses, primarily evapotranspiration and pumping. Groundwater-flow directions, recharge, and water quality of the water-table zone on the island were investigated by installing 26 shallow wells and three pond staff gages to monitor groundwater levels and water quality in the watertable zone. Climatic data from Brunswick, Georgia, were used to calculate potential maximum recharge to the water-table zone on Jekyll Island. A weather station located on the island provided only precipitation data. Additional meteorological data from the island would enhance potential evapotranspiration estimates for recharge calculations.

Groundwater levels and specific-conductance measurements showed the dependence of freshwater resources on rainfall to recharge the water-table zone of the surficial aquifer system and to influence groundwater flow on Jekyll Island. The unseasonably dry conditions during November 2012 to April 2013 induced saline water infiltration to the water-table zone from the marshland separating the Jekyll River from the island. A strong correlation $\left(\mathrm{R}^{2}=0.97\right)$ of specific conductance to chloride concentration in water samples from wells installed in the water-table zone provided support for the determination of seasonal directions of groundwater flow by confirming salinity changes in the water-table zone. Unseasonably wet conditions during the late spring to August caused groundwater-flow reversals in some areas. The high dependence of the water-table zone in the surficial aquifer system on precipitation to replenish the aquifer with freshwater underscored the importance of monitoring groundwater levels, water quality, and water use to identify aquifer-discharge conditions that have the potential to promote seawater encroachment and degrade freshwater resources on Jekyll Island.
\end{abstract}

\section{Introduction}

Development of groundwater resources in the shallow water-table zone of the surficial aquifer system for residential irrigation recently has increased at Jekyll Island, Georgia (fig. 1). The resultant water-table declines from pumping on this barrier island may threaten fragile coastal ecosystems by decreasing freshwater discharge to streams and marshlands, and increasing the salinity of these features by promoting seawater encroachment into the aquifer. Prolonged periods of excessively dry climatic conditions, such as drought, as well as sea-level rise, would compound water-table declines caused by increased pumping, as the freshwater supply on the island depends primarily on precipitation to replenish the aquifer.

Minimal information is available at Jekyll Island concerning groundwater hydrology, including pumping rates, recharge, and water levels in the water-table zone of the surficial aquifer system. Because pumping from the watertable zone of the surficial aquifer system is likely to increase, establishment of baseline hydrologic and water-quality conditions is critical for assessing current and future impacts of hydrologic stress on the island's freshwater resources and coastal ecosystem (AECOM, 2011).

Jekyll Island is a Georgia State Park governed by the Jekyll Island Authority (JIA). The JIA established a conservation planning committee to develop a long-term plan for the natural resources on Jekyll Island. The mission of the conservation plan is to "preserve, maintain, manage, and restore Jekyll Island's natural communities and species diversity while providing nature-based educational and recreational opportunities for the general public" (AECOM, 2011). The JIA is concerned that lowering the water table by increased pumping could adversely impact the environment through decreased periods of inundation in some areas, and promote seawater encroachment, ultimately resulting in detrimental salinity levels in freshwater systems and loss or degradation of wetlands. Objectives of the conservation plan include maintaining or improving salinity levels and water quality for salt marshes, wetland enhancement, and assessment of 

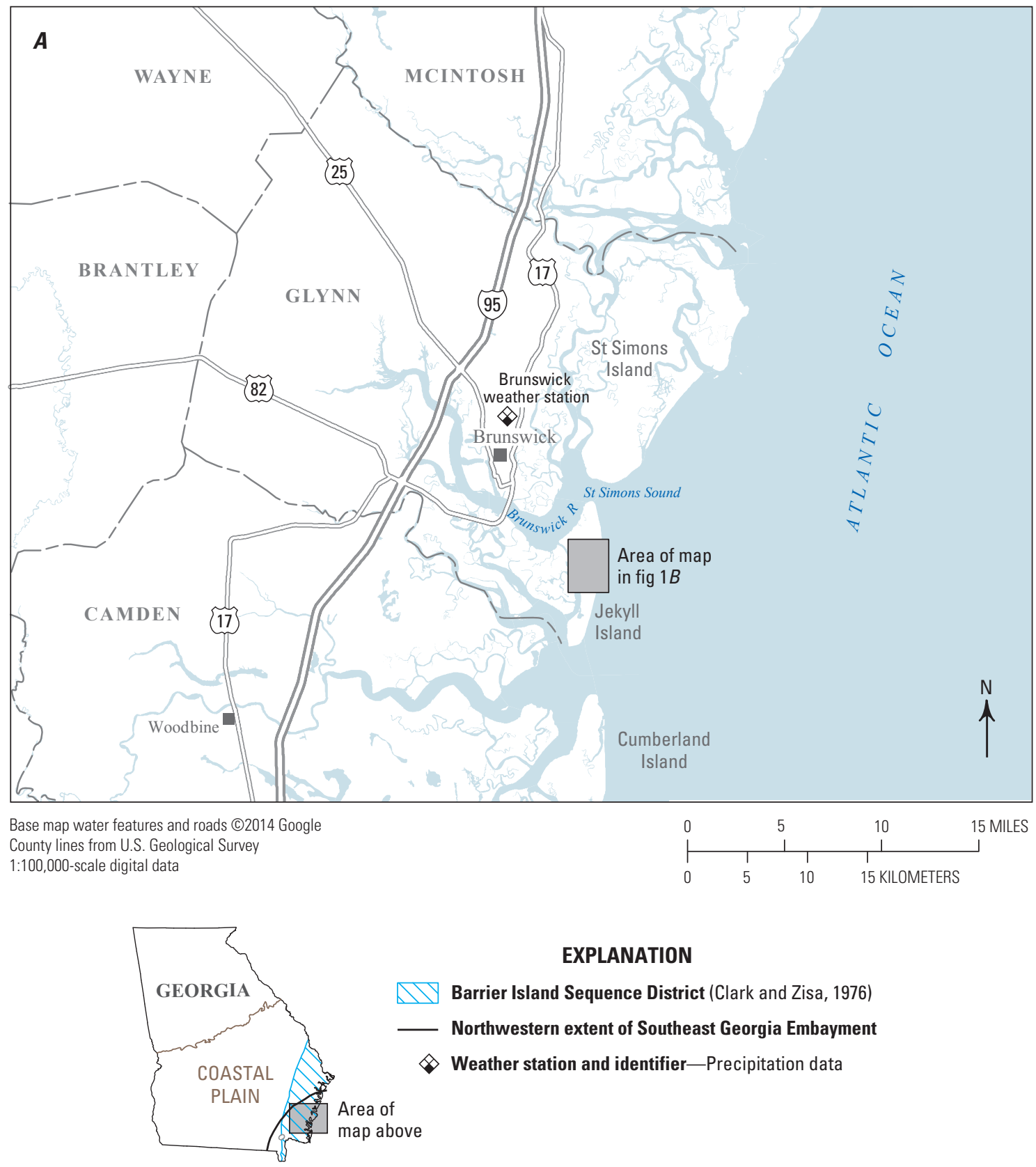

Figure 1. Location of $A$, Jekyll Island, Coastal Plain, study area; and $B$, monitoring wells and gages, Georgia.

regional changes in groundwater level and water quality. Strategies to meet plan objectives include assessing current groundwater levels to determine the effects of changes on wetland hydrology and monitoring salinity levels in wetlands and ponds for saltwater intrusion (AECOM, 2011).

The U.S. Geological Survey (USGS), in cooperation with the JIA, initiated a study during 2012 to monitor groundwater levels and assess baseline water quality in the water-table zone of the surficial aquifer system to assist in meeting some of the objectives of the JIA conservation plan. The objectives of the study were to
- Determine the number and distribution of shallow wells on Jekyll Island;

- Identify seasonal fluctuations of groundwater levels within the water-table zone of the surficial aquifer system;

- Estimate seasonal recharge to the water-table zone; and,

- Collect baseline water-quality data for the water-table zone for future comparison.

Data from this investigation add to the USGS database of hydrogeologic information that collectively improves regional characterization of surficial aquifers in coastal areas. 


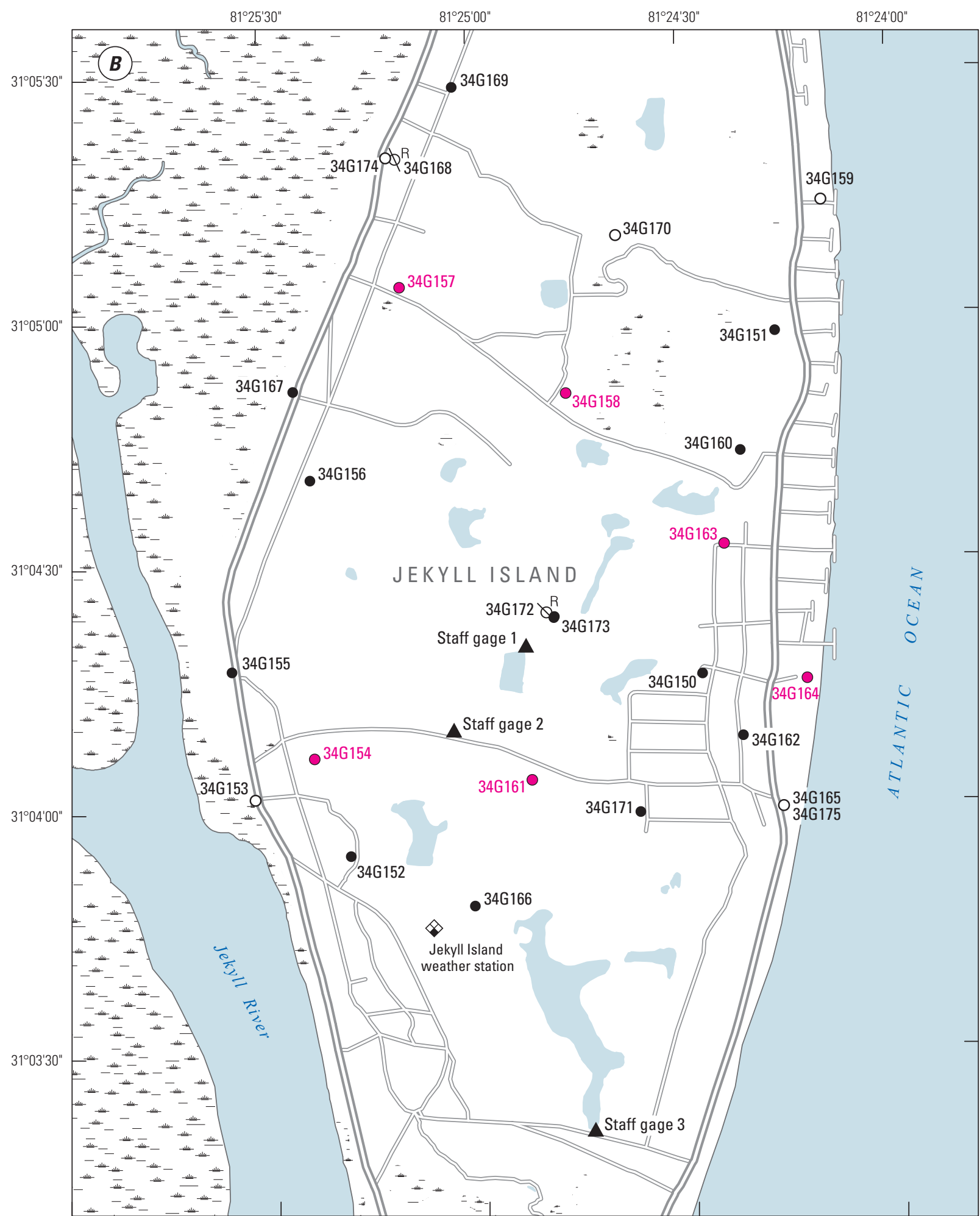

Base modified from ESRI Streetmap, 1:750,000. Map image is the intellectual property of Esri and is used herein under license. Copyright (2014 Esri and its licensors. All rights reserved

EXPLANATION

34G166 Monitoring well and identifier

34G157 Monitoring well and identifier-

Sampled for water-quality analyses

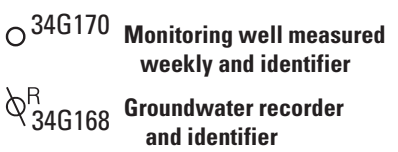

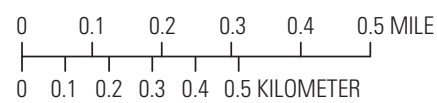

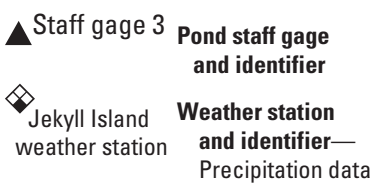

Figure 1. Location of $A$, Jekyll Island, Coastal Plain, study area; and $B$, monitoring wells and gages, Georgia.-Continued 


\section{Purpose and Scope}

This report documents hydrologic conditions and water quality in the water-table zone of the surficial aquifer system on Jekyll Island from October 2012 through December 2013. The study area encompasses the populated central portion of Jekyll Island (fig. $1 B$ ) where shallow residential wells have been installed primarily for lawn irrigation. The number and distribution of wells completed in the water-table zone of the surficial aquifer system have been described using results from an inventory of 89 wells made during November 2012. Seasonal groundwater-level measurements made in 26 wells (fig. $1 B$ ) installed in the water-table zone during this study between November 2012 and August 2013 were supported by weekly groundwater-level and pond-stage measurements (recorded by JIA) to describe groundwater-level fluctuations on the island. Selected field water-quality properties of specific conductance and water temperature were measured at these 26 wells to assess water quality.

Seasonal recharge to Jekyll Island's water-table zone was estimated from meteorological conditions measured on the island and at a nearby weather station in Brunswick, Ga. (fig. 1A). Groundwater recharge was estimated using water-balance calculations derived from precipitation, evapotranspiration (combined evaporation from wet surfaces and water-vapor release, or transpiration, from plants), and water-use estimates. The potential maximum recharge attainable on the island was estimated from a water balance derived from precipitation and potential evapotranspiration. Net recharge to (or discharge from) the water-table zone was calculated as the change in aquifer volume resulting from groundwater levels measured on November 8, 2012, and April 17 and August 23, 2013. All data collected during this investigation were entered into the USGS National Water Information System (NWIS; http://waterdata.usgs.gov/nwis) database from a geographic information system (GIS) database developed for this study.

\section{Previous Studies}

Several hydrologic studies pertinent to the evaluation of hydrologic conditions on Jekyll Island have been performed. A recent publication by Henry (2014) describes the geology of the Georgia Coast with an emphasis on sedimentation and erosional processes that led to the creation of Georgia's barrier island system, which includes Jekyll Island. Dilsaver (2004) discusses the formation of barrier island systems during the past 2 million years that resulted in the present barrier island system along the Georgia Coast. Clarke and others (1990) describe the geology and groundwater resources of the coastal area of Georgia and present well yields and surficial-aquifer properties in Glynn County. Watson (1982) presents well yields from shallow sands in Glynn County, and Leeth (1999) reports well yields and surficial-aquifer properties in Camden County. Chowns and others (2008) describe the stratigraphy and geology of coastal Georgia. Cherry and others (2010, 2011) describe groundwater conditions in the BrunswickGlynn County area of Georgia during 2009 and 2010.

\section{Description of Study Area}

Jekyll Island is located in Glynn County, just off the southeastern coast of Georgia, between St. Simons Island and Cumberland Island (fig. 1A). The island is bordered on the west by the Brunswick and Jekyll Rivers and on the east by the Atlantic Ocean (fig. 2). The island encompasses about 9 square miles ( $\mathrm{mi}^{2}$; about 5,800 acres) and has more than 1,750 ac of salt- and brackish-water tidal marsh, located primarily on the western part of the island and along streams (AECOM, 2011). The interior of the island contains mostly upland forest. Several ponds are located on the island, and dunes provide topographic relief between the coastline and the interior.

Land use on Jekyll Island is primarily forest and marsh (Cherry and others, 2011), and has been divided into six categories based on similarities in location, management requirements, and ecological function (AECOM, 2011). The categories and respective total acreages are as follows (fig. 2):

- beach and interdunal swale, including beach, primary dune, and an early successional back dune/swale system (475 acres);

- dry hammock, including naturally vegetated forested systems in the southern third of the island (368 acres);

- coastal marsh, including salt marshes, coastal creeks, and small forested islands (1,906 acres);

- upland forest, including pine and oak forests in the northern third of the island along with pockets of forested freshwater wetlands (1,069 acres);

- golf course, including forested systems within the golf courses, and the adjacent forested, freshwater wetlands (930 acres, four golf courses); and

- urban/park, including residential, commercial, historical district, and park land along the altered natural systems (1,099 acres). 


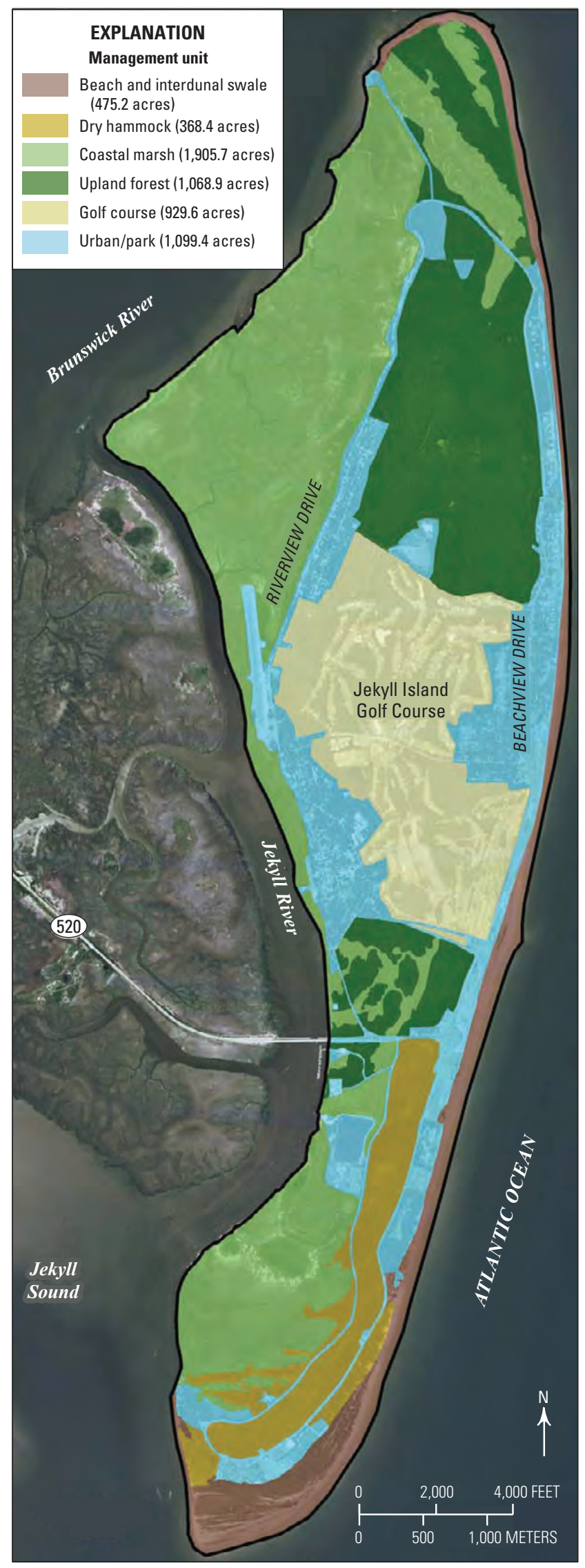

Figure 2. Land-use-based management units on Jekyll Island, Georgia (modified from AECOM, 2011).

\section{Physiography and Drainage}

Jekyll Island is located in the Barrier Island Sequence District of the Coastal Plain physiographic province (Clark and Zisa, 1976; fig. 1A). Land surface altitude ranges from sea level $[0$ feet $(\mathrm{ft})]$ along the coast and the Jekyll River to about $45 \mathrm{ft}$ along the dunes and in the northern interior part of the island (fig. 3).

Jekyll Island is bordered on the northwest by the Brunswick River, on the southwest by Jekyll Sound, on the east by the Atlantic Ocean, and on the west by the Jekyll River, which connects the Brunswick River to Jekyll Sound (figs. 2 and 3). Surface water generally drains from the interior of the island westward toward the wetlands and Jekyll River, eastward toward the Atlantic Ocean, and omni-directionally, converging in the southern part of the island at a large pond.

\section{Climate}

Although formal climatological records for Jekyll Island do not exist, climate records for nearby weather stations located along and near Georgia's 100-mile (mi) coastline provide insight into temperature and precipitation conditions on the Island (coastline data for Georgia obtained from U.S. Census Bureau, 2012). As one island in a sequence of barrier islands along the Georgia coast, Jekyll Island exhibits similarities in meteorological and climatologic conditions with the other islands and inland regions located within a relatively short distance of the coastline. The climate on Jekyll Island is moderate with temperatures averaging around 90 degrees Fahrenheit $\left({ }^{\circ} \mathrm{F}\right)$ in the summer and in the middle 50s during winter months. Precipitation typically is in excess of 50 inches per year with drier months during winter and about 20 inches of rain during summer months (hurricane season; The University of Georgia, Georgia State Climate Office, Driftmier Engineering Center, 1998)

No suitable long-term climate data are available for Jekyll Island, so climate data from a weather station in Brunswick, Glynn County, Georgia, located at the College of Coastal Georgia (Brunswick weather station, fig. 1) are presented and used along with precipitation data collected during this study on Jekyll Island to estimate the water balance. The period of record for the Brunswick weather station is 1999 to 2014, the average monthly high temperature ranges from 64 (January) to $91^{\circ} \mathrm{F}$ (July and August), the average monthly minimum temperature ranges from 43 (January) to $73^{\circ} \mathrm{F}$ (July and August), and the average annual precipitation is 50.7 inches (table 1; Georgia Automated Environmental Monitoring Network, 2016). Monthly total precipitation compiled for the weather station on Jekyll Island for 2013 shows that the island received above average precipitation during several months including April, May, August, September, and November (fig. 4; table 1). 


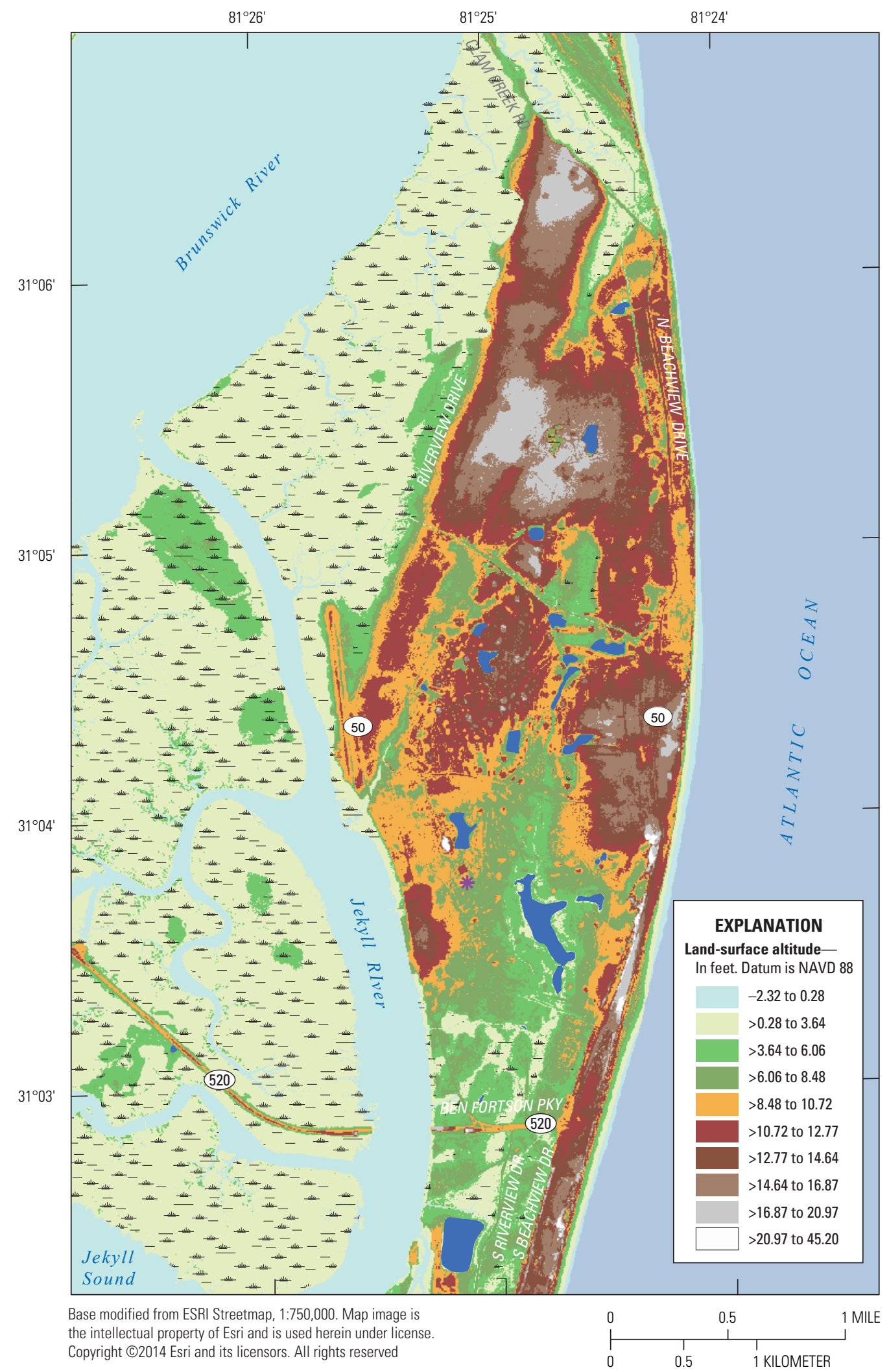

Figure 3. Light detection and ranging (lidar)-based altitude for central Jekyll Island, Georgia. 


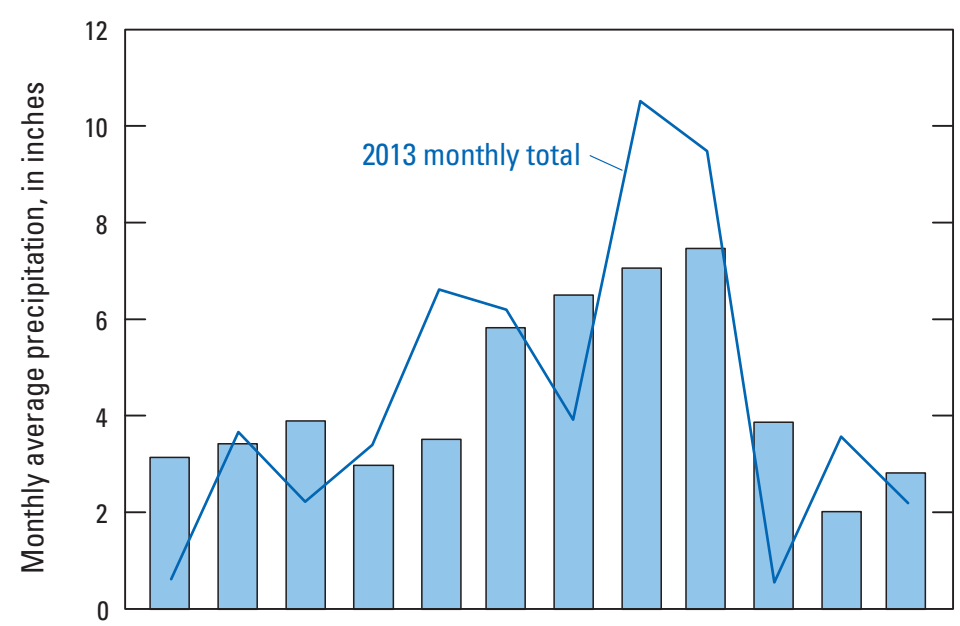

Jan. Feb. Mar. Apr. May June July Aug. Sept. Oct. Nov. Dec.

Month
Figure 4. Average monthly period of record precipitation for Brunswick, Georgia, and 2013 monthly total precipitation, in inches, at Jekyll Island, Georgia (Georgia Automated Environmental Monitoring Network, 2016).

Table 1. Period of record (1999 to 2012) average monthly temperature, precipitation, and evapotranspiration (ET) for Brunswick, Georgia.

[Data from Georgia Automated Environmental Monitoring Network, 2016; ${ }^{\circ} \mathrm{F}$, degrees Fahrenheit]

\begin{tabular}{|c|c|c|c|c|c|c|c|c|c|c|c|c|}
\hline & January & February & March & April & May & June & July & August & September & October & November & December \\
\hline \multicolumn{13}{|c|}{ Average monthly temperature $\left({ }^{\circ} \mathrm{F}\right)$} \\
\hline High & 64 & 66 & 72 & 78 & 84 & 89 & 91 & 91 & 87 & 80 & 71 & 65 \\
\hline Mean & 53 & 56 & 61 & 68 & 75 & 80 & 82 & 82 & 78 & 71 & 61 & 55 \\
\hline \multicolumn{13}{|c|}{ Average monthly total precipitation (inches) } \\
\hline \multicolumn{13}{|c|}{ Average monthly mean ET (inches) } \\
\hline & 1.09 & 1.76 & 2.95 & 4.27 & 5.15 & 5.15 & 5.19 & 4.60 & 3.68 & 2.57 & 1.56 & 0.65 \\
\hline
\end{tabular}




\section{Hydrogeology}

The hydrogeology of Jekyll Island is governed by various episodes of sedimentation and erosion unique to the formation of barrier islands located along Georgia's coast. These erosional and depositional episodes resulted in the formation of a surficial aquifer system on Jekyll Island that contains a water-table zone of interest to this study.

\section{Aquifer Formation on a Barrier Island}

The following descriptions of the formation of Georgia's barrier islands from Henry (2014) and Dilsaver (2004) provide insight into sedimentation and erosion patterns that led to the formation of Jekyll Island and the water-table zone of the surficial aquifer system. The barrier islands (and water-table zone) are composed of dune and beach ridge sands formed by the interaction of wind, waves, currents, sand supply, and a slowly rising or stable sea level (Henry, 2014). The lower Coastal Plain, containing the Barrier Island Sequence District (fig. 1A), described previously, extends $65 \mathrm{mi}$ inland from the coast and is distinguished by the ocean's highest incursion during the geologically recent Pleistocene epoch, which began almost 2 million years ago (Henry, 2014). Periodic stabilization in sea level has created seven identifiable lines of barrier islands on the Coastal Plain. Two barrier island formations deposited during the past 2 million years resulted in the present barrier island system along the Georgia coast, with the creation of a barrier island chain known as the Pleistocene Silver Bluff Formation (Dilsaver, 2004) ("Pleistocene Barrier Island Facies," shown in fig. 5).

During the Holocene (10,000 years ago to present), sea-level rise caused by melting glaciers led to the development of Holocene barrier formations that "migrated shoreward and become welded onto the Silver Bluff [Formation] islands" (Dilsaver, 2004) ("Holocene Barrier Island Facies," shown on fig. 5). "Jekyll Island is a composite barrier island consisting of a core of beach and dune deposits formed during the previous, and slightly higher, worldwide sea level of the Pleistocene Silver Bluff [compared with current sea level], approximately 40,000 to 50,000 years ago" (Henry, 2014).

The constant deposition of eroded material along a fluctuating coastline caused layering of sediments and created distinct strata that reflect the varying source material eroded

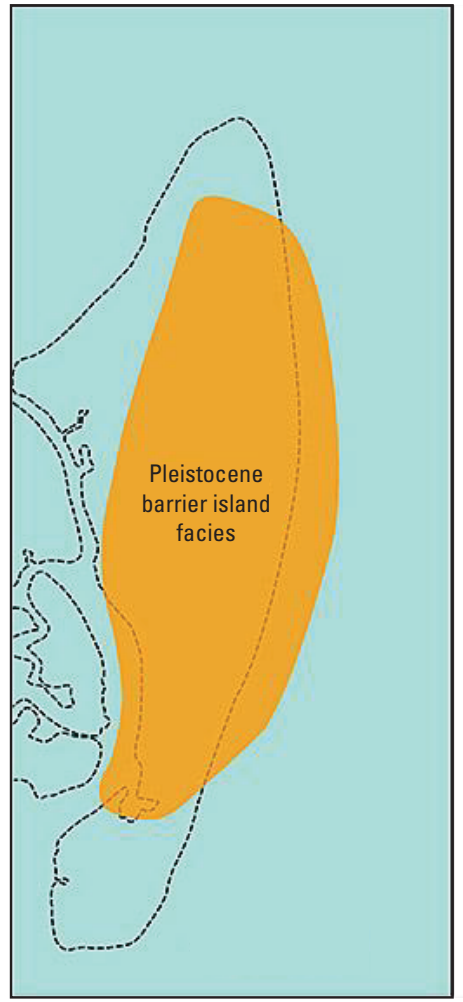

Approximately 50,000 years before present

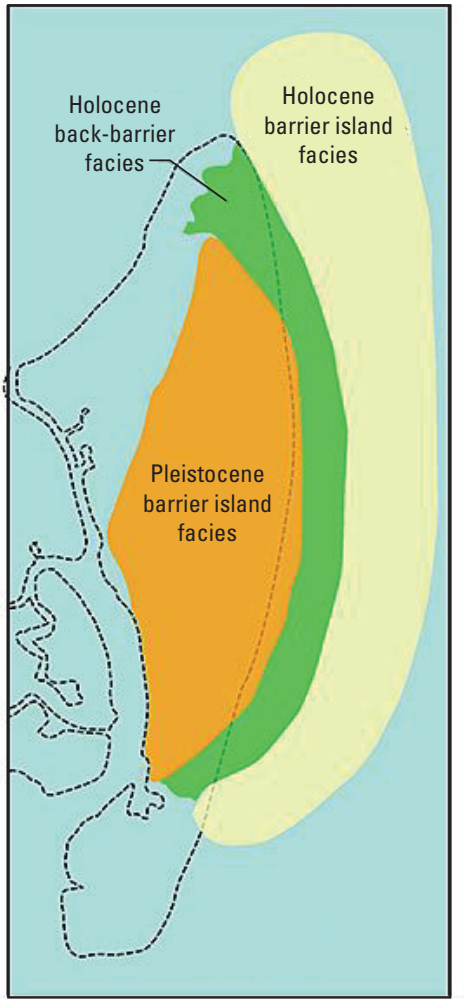

Approximately 5,000 years before present

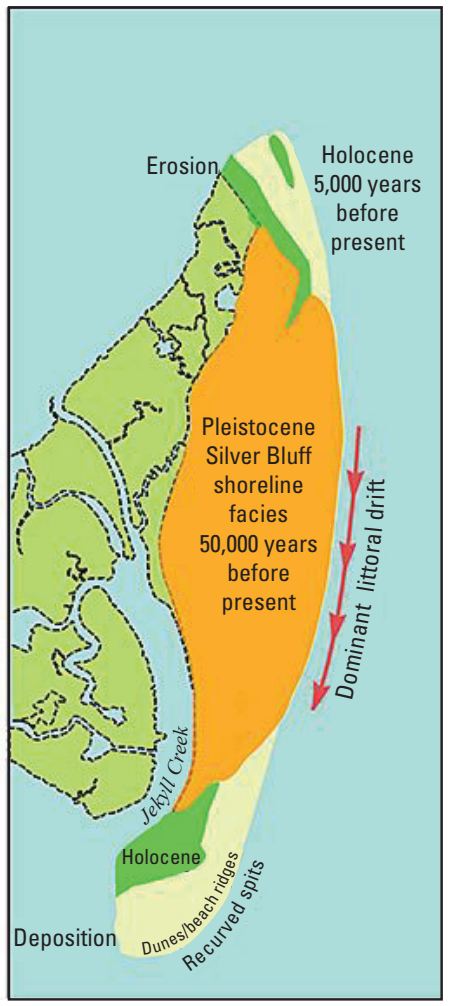

Present (2014)

Figure 5. Sedimentation and erosion features on Jekyll Island, Georgia (Henry, 2014). 
Introduction

away from the mainland and carried to the ocean by rivers (Dilsaver, 2004). Barrier islands, such as Jekyll Island, border the modern (Holocene) Georgia coast but are separated from the mainland by relatively deep tidal inlets, or sounds, creating a hydrogeology different than that of the mainland. Extensive sand shoal systems were deposited seaward of the inlets and central portions of the islands adding complexity to this hydrogeology (Henry, 2014). As described by Henry (2014), the Georgia Coast is a tide-dominated, low-wave energy coast due to its ebb-tide deltas, inlets, and relatively short, wide barrier islands. The ebb-tide-delta; the alongshore, downcurrent-drift-of-sediment ("dominant littoral drift," [fig. 5]); and the adjacent dynamic beach and dune system make up the coastal sand-sharing system where sand from the southern portion of one island welds onto and nourishes the northern (upcurrent) portion of an adjacent barrier island to the south. Disturbances to the system, such as inlet dredging, jetties, or shoreline armoring, disrupt the flow of sand to the downcurrent shorelines (fig. 5; Henry, 2014).

\section{Water-Table Zone of the Surficial Aquifer System}

The aforementioned erosional and depositional processes leading to the formation of Jekyll Island also created the water-table zone of the surficial aquifer system (fig. 6). Sands and muds of the Pleistocene Silver Bluff Formation (Chowns and others, 2008), Holocene dune sands, and undifferentiated Post-Miocene sediments deposited during formation of the barrier island, described in the previous section, constitute the shallow water-table zone of interest for this recharge study.

Although well yields from the surficial aquifer system on Jekyll Island have not been quantified through aquifer tests, yields of wells installed in surficial-aquifer material along the Georgia coast near Jekyll Island may give an indication of expected well yields on the island. Typical wells drilled to approximately $40 \mathrm{ft}$ in sands in Glynn County yielded 1-5 gallons per minute (gal/min) (Watson, 1982). Clarke and others (1990) and Leeth (1999) reported well yields of 2-140 gal/min, with transmissivity ranging from 14 to 6,700 feet squared per day $\left(\mathrm{ft}^{2} / \mathrm{d}\right)$, for a water-table zone underlain by confined zones within the surficial aquifer system in Glynn and Camden Counties, Georgia.

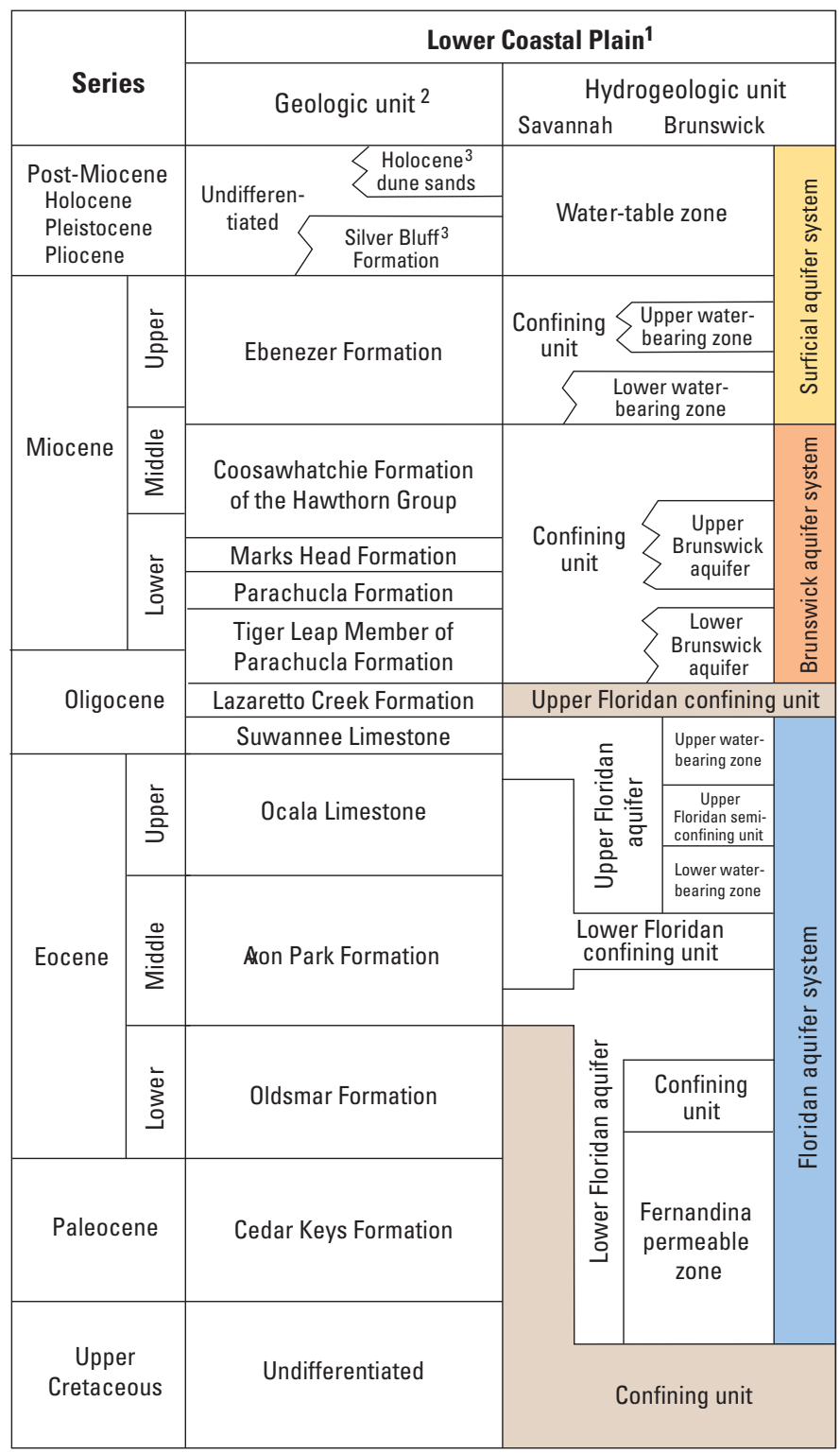

'Modified from Randolph and others, 1991; Clarke and Krause, 2000. ${ }^{2}$ Modified from Randolph and others, 1991; Weems and Edwards, 2001. ${ }^{3}$ Modified from Chowns and others, 2008.

Figure 6. Generalized correlation chart showing the geologic and hydrogeologic units at Jekyll Island composing the lower coastal plain, Georgia. 


\section{Methods of Investigation}

Several methods of investigation were used during this study to estimate the volume of water available and to determine the usefulness of the available water. Data were collected and compiled from new and existing sources to estimate water availability. Specific conductance data were collected to give an indication of the usefulness of the water.

\section{Volume Estimates}

An inventory of 89 existing residential wells assumed to be open to the water-table zone of the surficial aquifer system was performed during July 31-August 2, 2012 (appendix 1, table 1-1). Construction information for these wells was not available, and access was not adequate to obtain water-level measurements; therefore, the residential wells could not be used as monitoring wells for this study. Twenty-six shallow monitoring wells were installed to more accurately define the water-table surface of the surficial aquifer system (fig. $1 B$ ). The wells range from 7.4 to $29.0 \mathrm{ft}$ in depth and were constructed using schedule 40, 2-inch-diameter polyvinyl chloride (PVC) pipe with screens $5 \mathrm{ft}$ in length and a 0.01 -inch slot size (appendix 2, table 2-1). The monitoring wells were used to collect water-level data and to measure specific conductance. Lithologic samples were collected during well construction and used to characterize the soil type and geology.

Water levels were measured and recorded using a combination of continuous recorders, weekly measurements, and periodic measurements during dry and wet seasons. Two USGS-constructed wells were equipped with continuous recorders - well 34G172 in an upland recharge area in the center of the island and well 34G168 in a lowland discharge area in the northwestern part of the island. Weekly water-level measurements were made in six wells and at three pond staff gages (fig. $1 B$ ).

To determine seasonal variations in groundwater levels, in addition to the weakly and continuous water-level measurements, three water-table maps were constructed using data collected during three different times of the year. The maps were used to determine areas of recharge, discharge, and the direction of groundwater flow, and they serve as a basis for recharge computations. Determinations of recharge and discharge areas, as well as groundwater flow direction, were made on the basis of two criteria: (1) recharge typically occurs at higher altitudes and discharge typically occurs at lower altitudes, and (2) groundwater flows perpendicular to watertable contours and toward discharge areas.

Recharge calculations for Jekyll Island required meteorological data not available from the Jekyll Island weather station (fig. 1B), which supplied only rainfall data from October 2012 through December 2013. Other rainfall data and evapotranspiration values were obtained from a weather station at Brunswick, Georgia, identified in figure $1 A$ as the
Brunswick weather station (The University of Georgia College of Agricultural \& Environmental Sciences, 2015).

Two methods were used to estimate recharge to the water-table zone of the surficial aquifer system. The first method (method one) is a simple water-balance equation using precipitation and evapotranspiration data. Recharge estimates based on this first method represent the potential maximum recharge estimates since the only factors considered in the equation are precipitation and evapotranspiration. The second method (method two) is based on the differences in watertable altitudes during a wet and dry period; this method allows estimation of aquifer-volume change and computation of net usable recharge (or discharge), because all influences to the hydrologic system are reflected in the water levels. Therefore, recharge estimated using method one is the potential maximum recharge, and recharge estimated using method two is the net usable recharge.

For method one, the potential maximum recharge to the water-table zone of the surficial aquifer system on Jekyll Island was calculated using the following water-balance equation (Healy, 2010),

$$
R=P-E T,
$$

where

$$
\begin{aligned}
R & =\begin{array}{c}
\text { unit recharge to the surficial aquifer system } \\
\text { (recharge volume per unit area) [length]; }
\end{array} \\
P & =\text { precipitation [length]; and } \\
E T & =\text { evapotranspiration [length]. }
\end{aligned}
$$

Method two, net useable recharge or discharge, uses the altitude of the water table. The altitude of the water table (or groundwater level) responds to precipitation (mostly rainfall) and evapotranspiration, and other hydrologic stresses, such as pumping, surface runoff to ponds, groundwater discharge to streams, and soil-moisture changes, as mentioned previously. Barometric-pressure changes, tides, and seawater rise also affect the water table. Groundwater-level measurements made during a given time period document changes to the water table and aquifer volume that indicate either net usable recharge (positive aquifer-volume change during a wet time period) or discharge (negative aquifer-volume change during a dry time period) with regard to the water-table zone of the surficial aquifer system. Differences in water-table altitudes during the wet and dry periods allow estimation of aquifervolume change and computation of net usable recharge (or discharge) in a manner similar to that of the "water-table fluctuation" method of Healy (2010). Usable recharge is the water available for potential development.

Aquifer-volume change and subsequent net usable recharge or discharge were calculated on Jekyll Island from groundwater levels measured on November 8, 2012, and April 17 and August 23, 2013 (appendix 3, table 3-1). The area of Jekyll Island, which is about $9 \mathrm{mi}^{2}$ or $250,905,600$ square feet $\left(\mathrm{ft}^{2}\right)$, was used in aquifer-volume and recharge (or discharge) calculations. When multiplied 
by aquifer porosity, aquifer-volume change during a wet time period (positive aquifer-volume change) represents net usable recharge, $R_{n e t}$, to the water-table aquifer and is given by (Buddemeier and Schloss, 2000),

$$
R_{n e t}=n \times\left[V\left(t_{2}\right)-V\left(t_{1}\right)\right]\left[\text { Length }^{3}\right]
$$

where,

$$
\begin{aligned}
& V\left(t_{2}\right) \quad \text { is aquifer volume at the end of the wet time } \\
& \text { period, } t_{2} \text { (high groundwater levels) } \\
& {\left[\text { Length }^{3}\right]}
\end{aligned}
$$

$V\left(t_{1}\right) \quad$ is aquifer volume at the beginning of the wet time period, $t_{1}$ (low groundwater levels) [Length ${ }^{3}$; and,

$n \quad$ is porosity [0] (dimensionless).

Discharge from the water-table zone of the surficial aquifer system also is given by equation 2 with the following changes: $V\left(t_{2}\right)$ represents aquifer volume at the end of a $d r y$ time period (low groundwater levels); and $V\left(t_{l}\right)$ represents aquifer volume at the beginning of a dry time period (high groundwater levels), such that the difference, $V\left(t_{2}\right)-V\left(t_{1}\right)$, yields a negative aquifer-volume change.

A porosity of 0.21 ( 21 percent by volume) was used to compute $R_{n e t}$ according to equation 2 . This value is characteristic of the porosity of sand containing some intermittent silt and clay (Fetter, 2001), which is similar to the barrier island sediments composing the water-table zone of the surficial aquifer system on Jekyll Island.

Calculation of $R_{\text {net }}$ by equation 2 can be simplified by factoring the area of Jekyll Island, about $9 \mathrm{mi}^{2}$ or $250,905,600 \mathrm{ft}^{2}$, from the aquifer volumes, $V\left(t_{2}\right)$ and $V\left(t_{1}\right)$, and expressing $R_{n e t}$ as a function of the average change in groundwater levels during two time periods, $t_{2}$ and $t_{1}$, as,

$$
R_{\text {net }}=n \times A \times\left[h_{\text {avg }}\left(t_{2}\right)-h_{\text {avg }}\left(t_{1}\right)\right]\left[\text { Length }^{3}\right] ;
$$

where

$A \quad$ is the area of Jekyll Island; and

$h_{\text {avg }}\left(t_{2}\right)$ and $h_{\text {avg }}\left(t_{1}\right)$ are average groundwater levels calculated from water levels measured at the beginning $\left(t_{1}\right)$ and end $\left(t_{2}\right)$ of the time period.

\section{Usefulness}

Specific conductance analyzed from water samples taken at the six baseline wells was plotted against chloride concentration to determine the correlation between the two constituents (fig. 7). In general, specific conductance (SC) is a measure of water's ability to conduct an electric current. Water that contains a high concentration of dissolved solids, especially salts, typically contains high values of SC. Specific conductance has been shown to be a reasonable surrogate for chloride concentration (Cherry and others, 2010, 2011).
A linear regression of the chloride-concentration and specific-conductance data from the six baseline wells on Jekyll Island resulted in a coefficient of determination $\left(\mathrm{R}^{2}\right.$ value $)$ of 0.75 , indicating that a relatively good linear relation existed for specific conductance to estimate chloride concentration. The sample from well 34G158 contained a low chloride concentration of 43 milligrams per liter $(\mathrm{mg} / \mathrm{L})$ and a fairly high SC value of 1,147 microsiemens per centimeter at 25 degrees Celsius $\left(\mu \mathrm{S} / \mathrm{cm}\right.$ at $\left.25^{\circ} \mathrm{C}\right)$, relative to the other five samples. This sample also had an alkalinity of $375 \mathrm{mg} / \mathrm{L}$, much higher than that of any other sample (table 2). The high SC in well $34 \mathrm{G} 158$ is probably due to carbonate and (or) bicarbonate being the dominant anion in the sample, as indicated by the high alkalinity. In addition, when this well was drilled and developed, the water pumped from the well remained cloudy, unlike the water from the other wells. Removing well 34G158 data from the graph yielded a linear correlation with $\mathrm{R}^{2}=0.97$, which indicates the linear relation is very good and may be used with confidence to estimate chloride concentration in samples not affected by carbonate or bicarbonate (fig. 2). Using information from the best-fit regression, the following relation was obtained:

Chloride concentration $($ in $\mathrm{mg} / \mathrm{L})=$

Specific conductance (in $\mu \mathrm{S} / \mathrm{cm}) \times 0.291-50.988 \mu \mathrm{S} / \mathrm{cm}$

where

0.291 represents the slope of the regression line, and $-50.988 \mu \mathrm{S} / \mathrm{cm}$ represents the y-intercept.

This relation is similar to the one established by Cherry and others (2011) for samples collected from the Upper Floridan aquifer near Brunswick, Georgia.

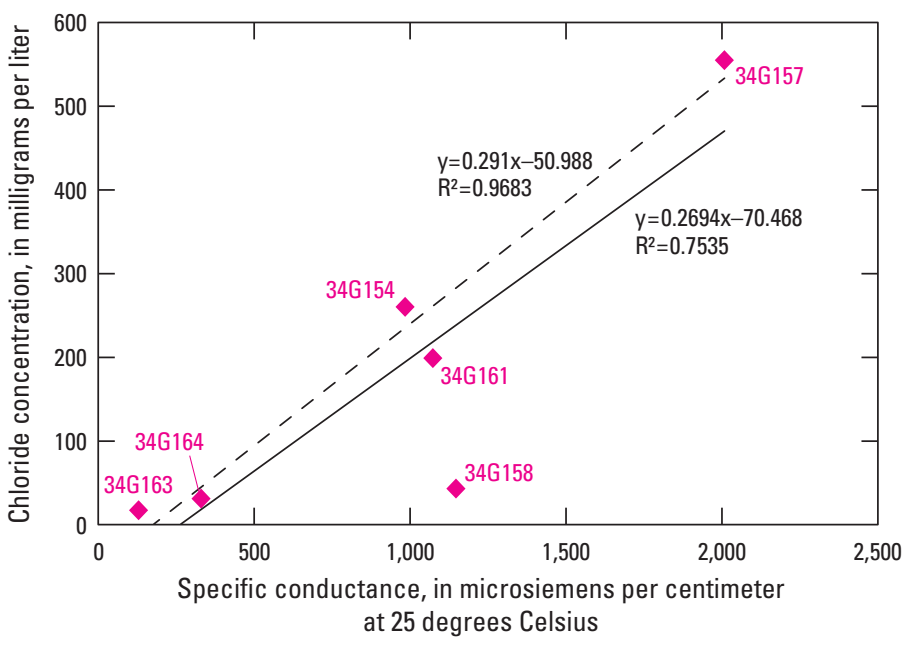

Figure 7. Ordinary least squares regression line between specific conductance and chloride concentration for wells completed in the surficial aquifer system, Jekyll Island, Georgia. The solid line represents all six data points, whereas the dashed line excludes the anomalous data point from well $34 \mathrm{G} 158$. 
Table 2. Groundwater-quality data for the surficial aquifer system, Jekyll Island, Georgia, August 23, 2013.

[TDS, total dissolved solids; $\mathrm{mg} / \mathrm{L}$, milligrams per liter; $\mu \mathrm{S} / \mathrm{cm}$ at $25^{\circ} \mathrm{C}$, microsiemens per centimeter at 25 degrees Celsius; $\mathrm{CaCO}_{3}$, calcium carbonate]

\begin{tabular}{|c|c|c|c|c|c|c|}
\hline $\begin{array}{c}\text { USGS } \\
\text { well } \\
\text { identifier }\end{array}$ & $\begin{array}{c}\text { TDS } \\
\text { concentration } \\
\text { (mg/L) }\end{array}$ & $\mathrm{pH}$ & $\begin{array}{c}\text { Specific } \\
\text { conductance } \\
\left(\mu \mathrm{S} / \mathrm{cm} \text { at } 25^{\circ} \mathrm{C}\right)\end{array}$ & $\begin{array}{c}\text { Chloride } \\
\text { concentration } \\
\text { (mg/L) }\end{array}$ & $\begin{array}{c}\text { Alkalinity } \\
\text { (mg/L) }\end{array}$ & $\begin{array}{c}\text { Hardness } \\
\left(\mathrm{mg} / \mathrm{L} \text { as } \mathrm{CaCO}_{3} \text { ) }\right.\end{array}$ \\
\hline $34 \mathrm{G} 154$ & 1,875 & 5.74 & 984 & 260 & 35 & Too turbid \\
\hline $34 \mathrm{G} 157$ & 2,993 & 5.66 & 2,008 & 555 & 10 & Too turbid \\
\hline $34 \mathrm{G} 158$ & 1,025 & 6.23 & 1,147 & 43 & 375 & 340 \\
\hline $34 \mathrm{G} 161$ & 840 & 5.61 & 1,073 & 199 & 25 & 340 \\
\hline $34 \mathrm{G} 163$ & 214 & 4.63 & 130 & 17 & $<10$ & 120 \\
\hline $34 \mathrm{G} 164$ & 547 & 6.01 & 330 & 31 & 55 & 160 \\
\hline
\end{tabular}

\section{Surficial Aquifer System Water Use}

Most of the inventoried residential wells are less than $40 \mathrm{ft}$ deep, consistent with wells in Glynn and Camden Counties, Georgia, from which well-yield information had been mentioned in a previous section. The well inventory for this study confirmed that well water from private wells on Jekyll Island is used mostly for lawn irrigation. Municipal water is provided by the JIA from wells pumping from the Brunswick and Upper Floridan aquifer systems (fig. 6). The total number of wells inventoried (89) constituted about one quarter of the 350 total residential wells installed on Jekyll Island (John Day, JIA, oral commun., July 31, 2012), and is assumed herein to be a representative sample of the total population of residential wells (350) on the island. These 350 wells supply water to about half of the 700 residences on Jekyll Island (James Kennedy, Georgia Environmental Protection Division, written commun., January 26, 2008).

According to the U.S. Environmental Protection Agency (EPA), the average U.S. household uses 320 gallons per day (gal/d), about $96 \mathrm{gal} / \mathrm{d}$ of which is used for outdoor purposes (U.S. Environmental Protection Agency, 2014). Assuming the 350 residential wells on Jekyll Island use water for outdoor purposes (lawn irrigation) at a rate of about $96 \mathrm{gal} / \mathrm{d}$, then an estimated 33,600 gal/d (350 residences multiplied by $96 \mathrm{gal} / \mathrm{d}$ ) of water is pumped from the water-table zone of the surficial aquifer system by residential wells on Jekyll Island.

\section{Hydrologic Conditions of the Water-Table Zone of the Surficial Aquifer System}

Hydrologic conditions affecting the quantity and distribution of freshwater resources in the water-table zone of the surficial aquifer system on Jekyll Island were investigated to assess water availability and use and to inform management decisions regarding development potential of the island's water resources. Groundwater-flow directions inferred from water-level measurements and supported by specificcapacity data helped identify areas of potential recharge to and discharge from the water-table zone. Meteorological data collected during this study and similar data compiled from the Brunswick weather station contributed to recharge estimates calculated for the island. Evaluating the hydrologic conditions of the water-table zone promoted understanding of the hydrologic stresses affecting recharge and provided the essential elements for investigating hydrologic conditions that contribute to the water resources on Jekyll Island.

\section{Groundwater-Flow Directions and Inferred Recharge and Discharge}

Directions of groundwater flow in the water-table zone of the surficial aquifer system were determined from water-table maps constructed using groundwater levels that were measured in the 26 wells installed during this study (fig. $1 B$ and appendices 2 and 3). Groundwater-level measurements made on November 8, 2012, April 17, 2013, and August 23, 2013, provided the basis for seasonal water-table maps to delineate groundwater-flow directions and infer potential recharge and discharge areas (fig. $8 A-C$ ). Three pond staff gages installed during this study (fig. $1 B$ ) identified the surface expression of the water table on Jekyll Island and support the delineation of recharge and discharge areas in the water-table zone. Two criteria were used to identify groundwater-flow directions and infer recharge and discharge areas from the water-table maps: (1) groundwater flows perpendicular to water-table contours, from high to low water-level altitudes; and (2) recharge generally occurs where water-table contours indicate divergent groundwater flow at relatively high water-level altitudes; discharge generally occurs where water-table contours indicate convergent groundwater flow at relatively low water-level altitudes. 


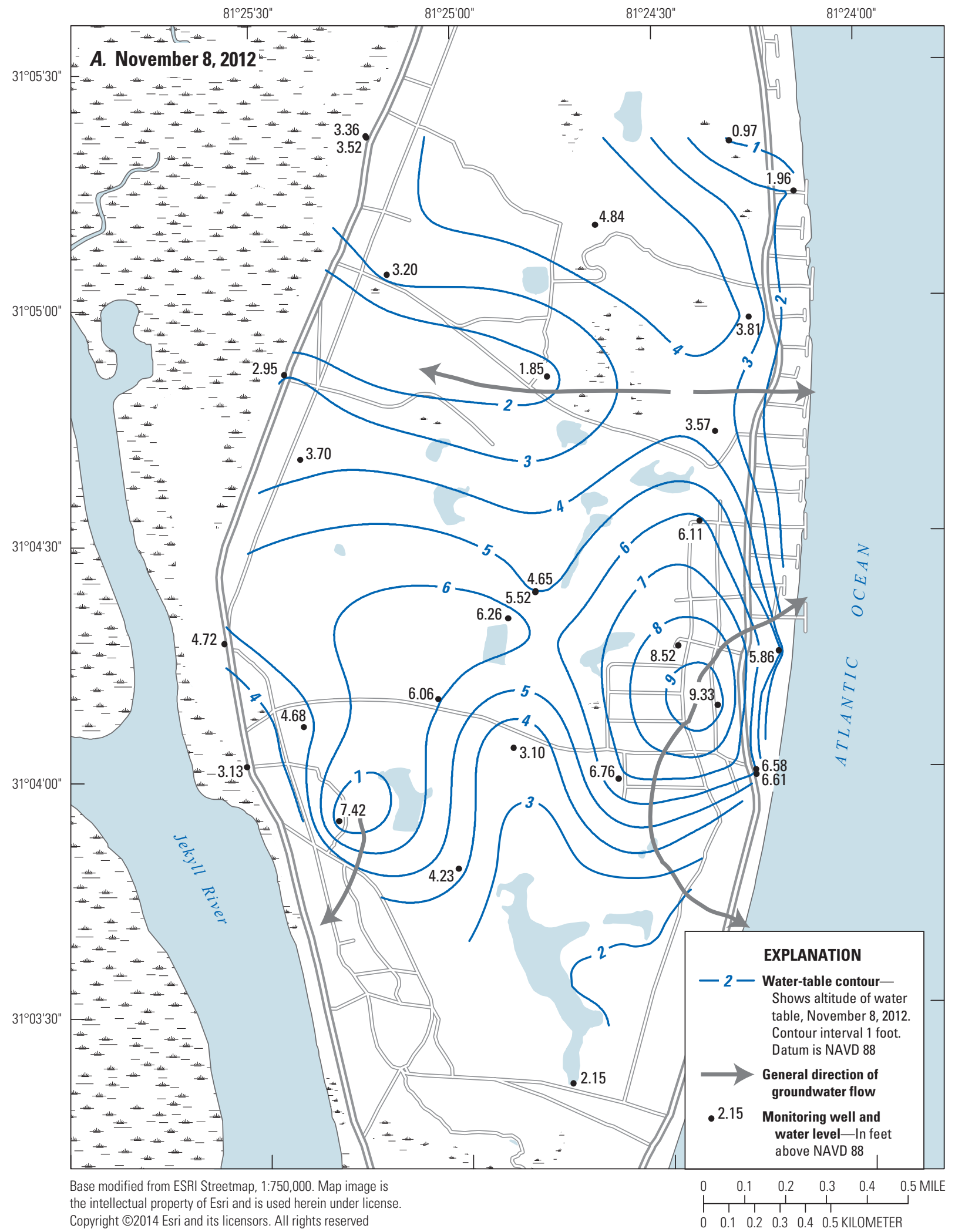

Figure 8. Water table for, $A$, November 8, 2012; B, April 17, 2013; and C, August 23, 2013 on Jekyll Island, Georgia. 


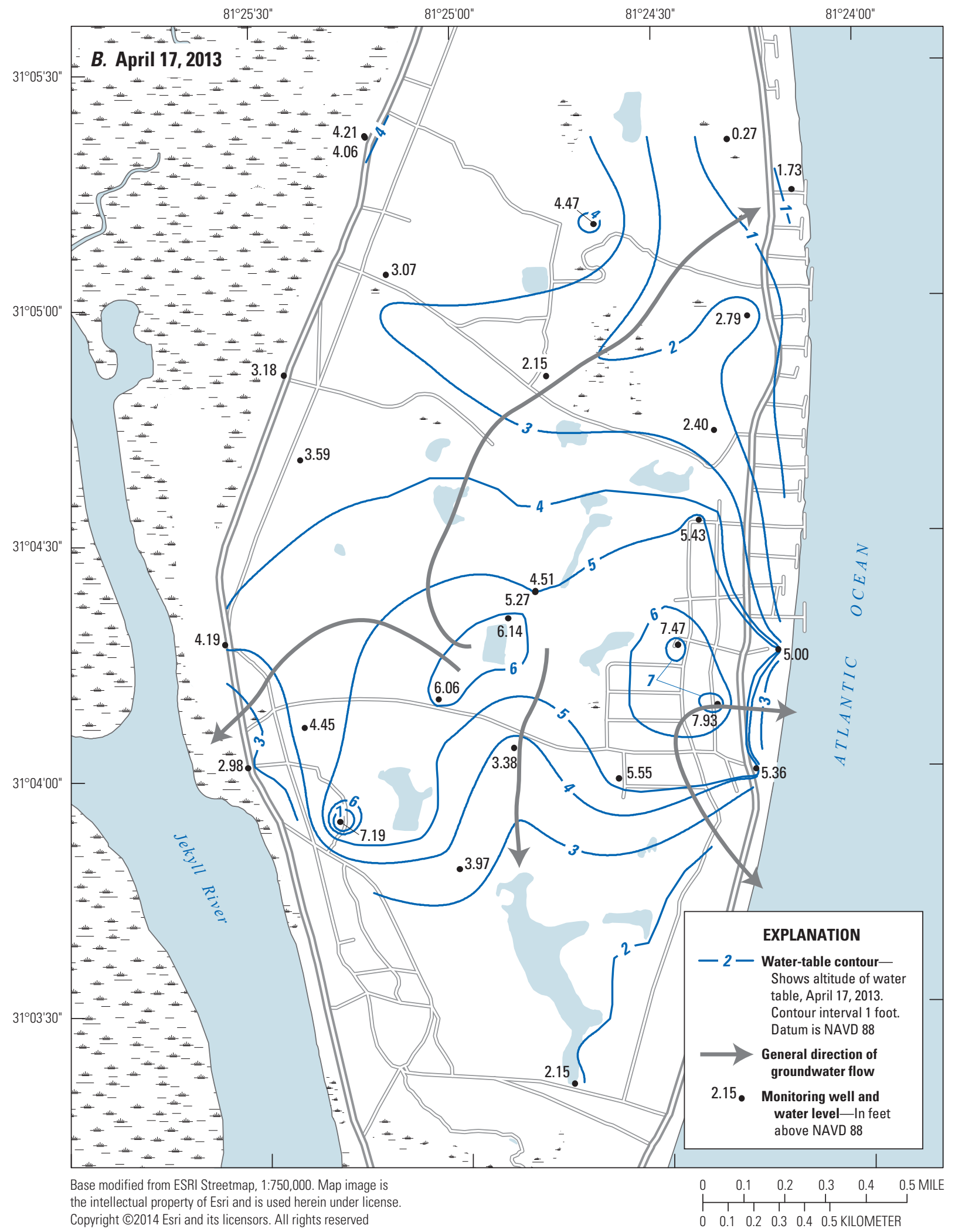

Figure 8. Water table for, $A$, November 8, 2012; B, April 17, 2013; and $C$, August 23, 2013 on Jekyll Island, Georgia.Continued 


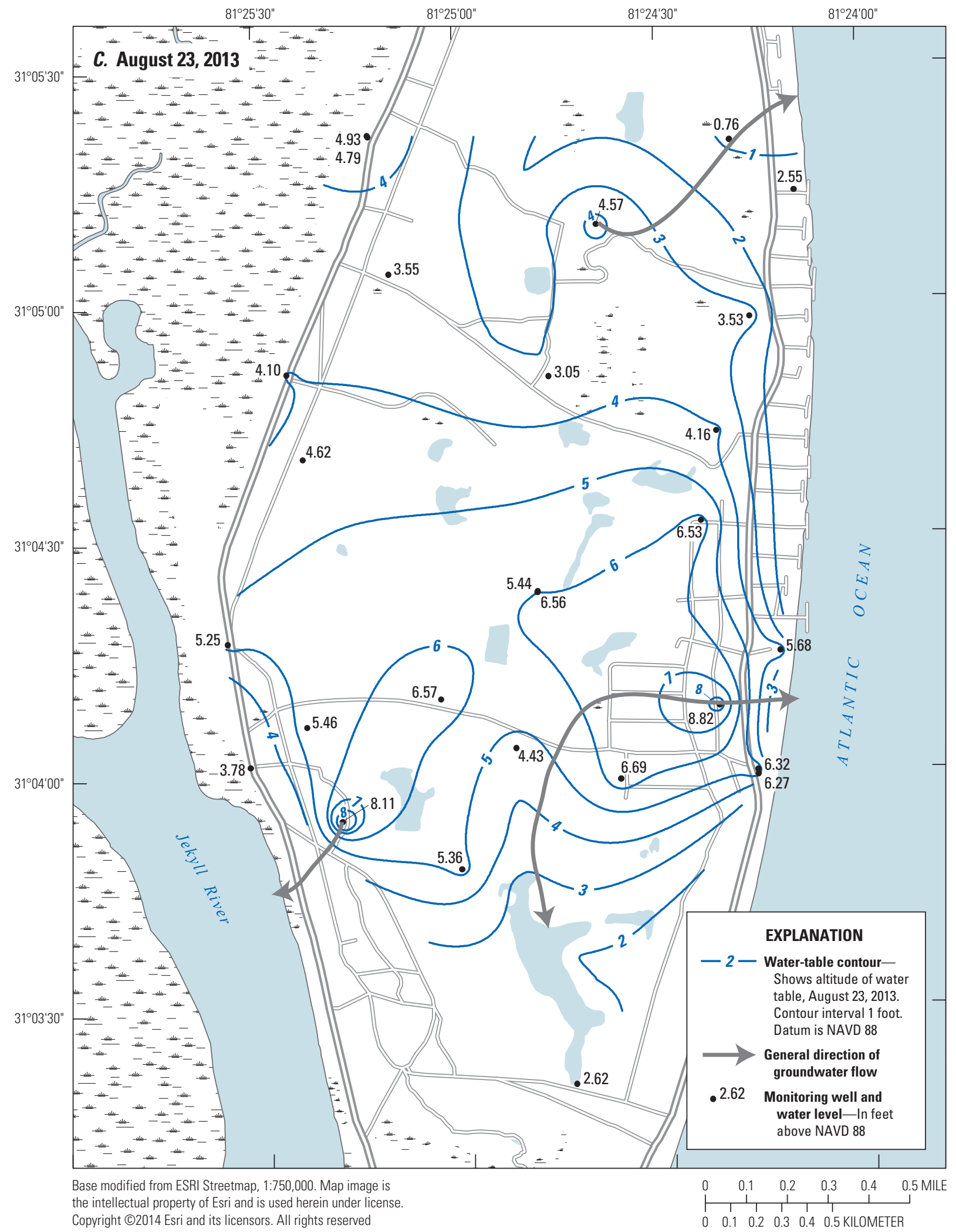

Figure 8. Water table for, A, November 8, 2012; B, April 17, 2013; and C, August 23, 2013 on Jekyll Island, Georgia.Continued 
Maps depicting the water table of the water-table zone of the surficial aquifer system indicate complex groundwaterflow directions that infer recharge and discharge areas on Jekyll Island. Closed 6-, 7-, and 8-ft water-table contours encircle relatively high water levels near the southwestern part of the island, indicating recharge during the three measurement periods (November 8, 2012, April 17, 2013, and August 23, 2013) (figs. 8A-C). During the April 17, 2013, measurement period, the 6 -ft water-table contour encircled a small pond near the center of the island, indicating that the pond functioned as a recharge area to the water-table zone (fig. $8 B$ ). The pond possibly accumulated direct precipitation and surface runoff of precipitation, which elevated the pond stage and water table (see "Staff gage 1," fig. 9), creating a recharge area for the water-table zone of the surficial aquifer system. The pond stage at staff gage 1 rose about $0.3 \mathrm{ft}$ following rainfall recorded on Jekyll Island during early May 2013 (fig. 9). This elevated pond stage could have further contributed to recharge of the water-table zone that could not be depicted by water levels measured in April 2013.

Another recharge area located east of the area described above is inferred from the closed 6- to 9-ft water-table contours that resulted from the November 8, 2012, groundwater-level measurements (fig. $8 A$ ). The water table declined slightly more than a foot by the April 17, 2013, measurement period (fig. $8 B$ ), and then increased nearly a foot by the August 23, 2013, measurement period (fig. 8C), perhaps the result of relatively low rainfall in the spring, lawn irrigation, and relatively high rainfall during August, 2013 (fig. 9). The seasonal effects of rainfall and lawn irrigation on groundwater levels are described in the next section of this report.

Several areas of groundwater discharge from the watertable zone of the surficial aquifer system on Jekyll Island were inferred from the seasonal water-table maps prepared from groundwater levels and pond stages measured during November 8, 2012, April 17, 2013, and August 23, 2013 (figs. $8 A-C$ ). The recharge area established in the southwestern part of the island, described above, provided the hydraulic potential for discharge westward into the Jekyll River (figs. $8 \mathrm{~A}, \mathrm{C}$ ). In the south-central part of the island, the 3-, 4-, and 5-ft water-table contours indicated groundwater discharge and converging flow toward a large pond. Watertable contours for the three measurement periods indicated that the recharge areas previously discussed supply groundwater to this pond. Further, the pond seems to stabilize groundwater levels surrounding it, maintaining a stage almost exclusively between 2 and $3 \mathrm{ft}$ (see "Staff gage 3," fig. 9) during the measurement periods.

Groundwater levels measured during three periods in 2012 and 2013, defined previously, and pond stages recorded during these periods indicate that the eastern coast of Jekyll Island represents the principal discharge area for the watertable zone of the surficial aquifer system (figs. $8 A-C$ ). The recharge area inferred from the 6- to 9-ft closed contours creates a relatively steep hydraulic gradient toward the coast in the east-central part of the island. This positive hydraulic gradient is maintained, although diminished, at the northern and southern extents of this recharge area along the eastern coast of the island.

Groundwater levels measured in the north-central part of Jekyll Island indicate that the water-table zone of the surficial aquifer system in this region fluctuates seasonally between recharge and discharge (figs. $8 A-C$ ). The 2- and 3-ft water-table contours in the north-central part of Jekyll Island during November 8, 2012, indicate converging groundwater flow and discharge westward toward the marshland adjacent to the Jekyll River. Diverging groundwater flow indicating groundwater recharge is inferred from the November 8, 2013, measurements in the area enclosed by the northernmost $4-\mathrm{ft}$ water-table contour (fig. $8 A$ ). Groundwater levels measured during April 17, 2013, however, delineated a discharge area of the water-table zone in the opposite direction to that identified by the November 8, 2012, water levels. That is, for April 17, 2013, the 2- and 3-ft water-table contours indicate flow eastward toward a wetland located in the east-central part of the island (fig. 8B). During the August 23, 2013, measurement period, the 4-ft water-table contours infer discharge areas at the location of this east-central-island marsh, with groundwater flow westward toward the marshland located adjacent to the Jekyll River where the November 8, 2012, groundwater levels also indicated discharge (fig. $8 A$ ).

\section{Seasonal Water-Table Fluctuations}

During 2013, weekly water-level measurements were made in 6 of the 26 wells installed for this study in the watertable zone of the surficial aquifer system, and continuous water levels were recorded in 2 of these wells to identify seasonal fluctuations in the water table (fig. 9; see fig. 1 for locations). Weekly and continuously measured water levels ranged from 0.5 to $12.21 \mathrm{ft}$ below land surface during 2013, fluctuating in response to rainfall, or lack thereof, recorded at the Jekyll Island weather station (see fig. 1 for location). All weekly and continuously measured wells began 2013 with seasonal-low water levels, a result of low rainfall during November and December 2012 (fig. 9). Rainfall on Jekyll Island during late February, late March, and early May 2013 triggered sharp water-level increases. Most of the weekly and continuously measured wells exhibited a water-level increase by the end of 2013, indicating annual net recharge to the water-table zone of the surficial aquifer system.

The seasonal water-level decline in the water-table zone of the surficial aquifer system during May-August 2013 (fig. 9) possibly resulted from residential lawn irrigation and subsequent evapotranspiration of the water applied as well as natural vegetative uptake. Weekly and continuous water levels indicate a steady decline interrupted briefly by early June rainfall.

Weekly and continuously recorded water levels in the water-table zone of the surficial aquifer system on Jekyll Island exhibited a relatively rapid rise followed by an almostas-rapid decline in response to rainfall amounts (fig. 9). This near-term water-level response to hydrologic stress indicates 


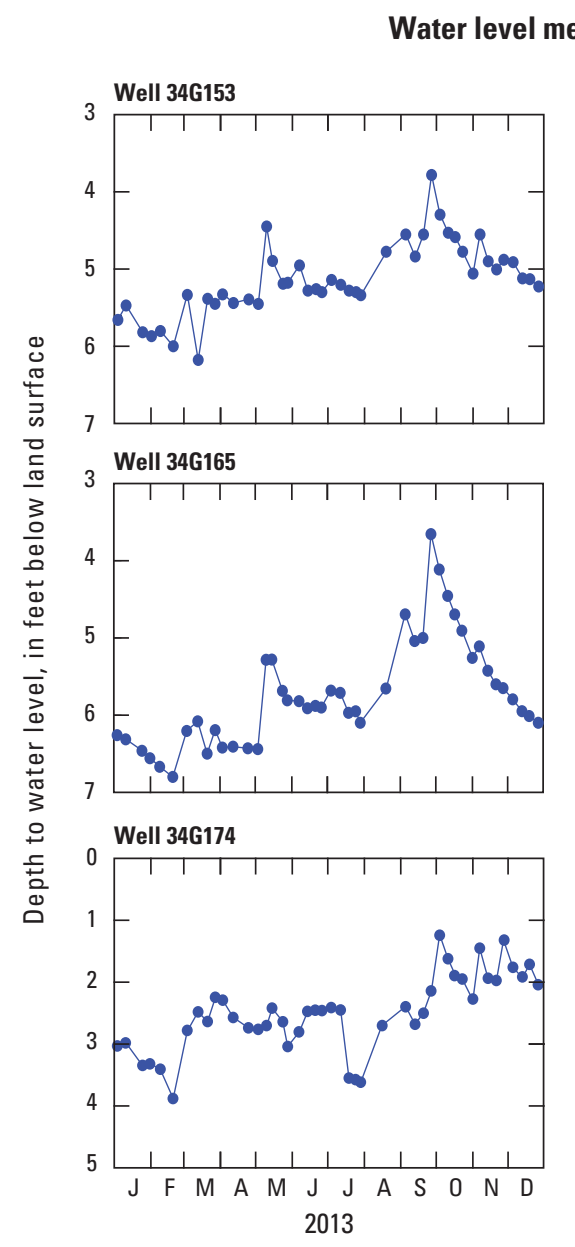

measured weekly
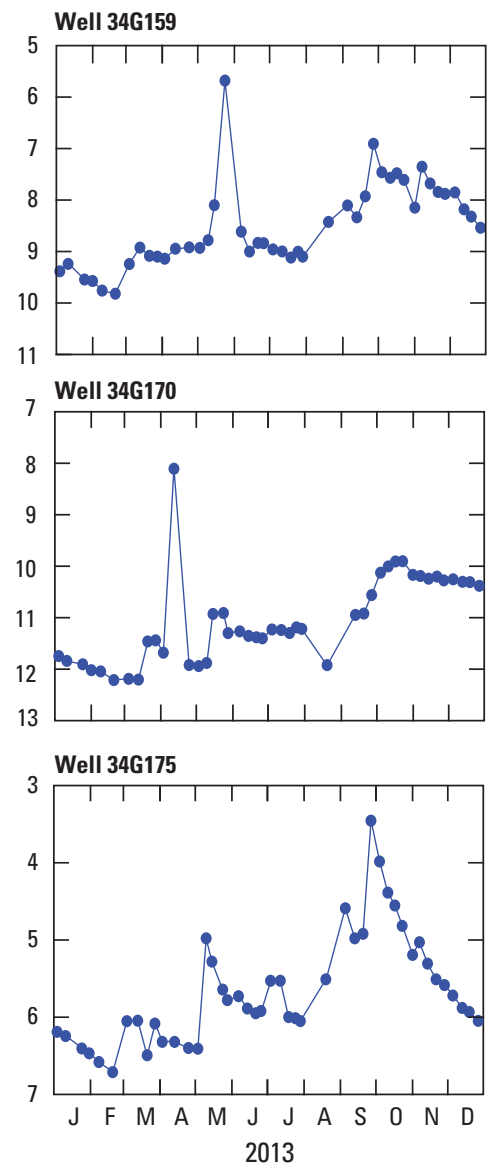

Pond stage

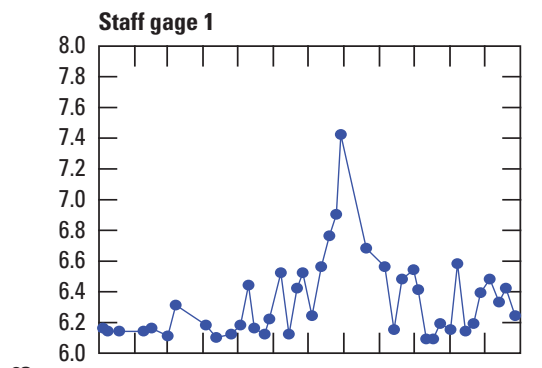

$\infty$

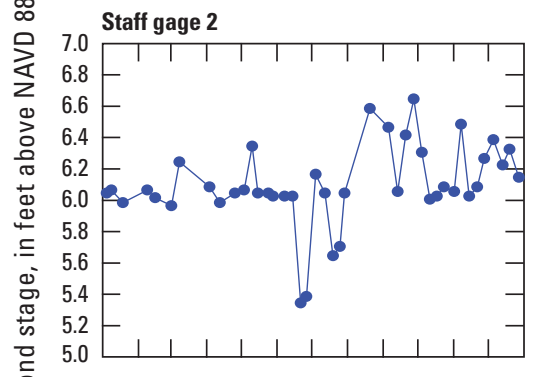

잉

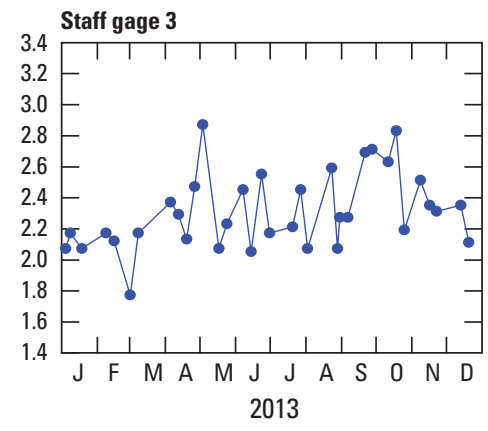

\section{Continuous water level}
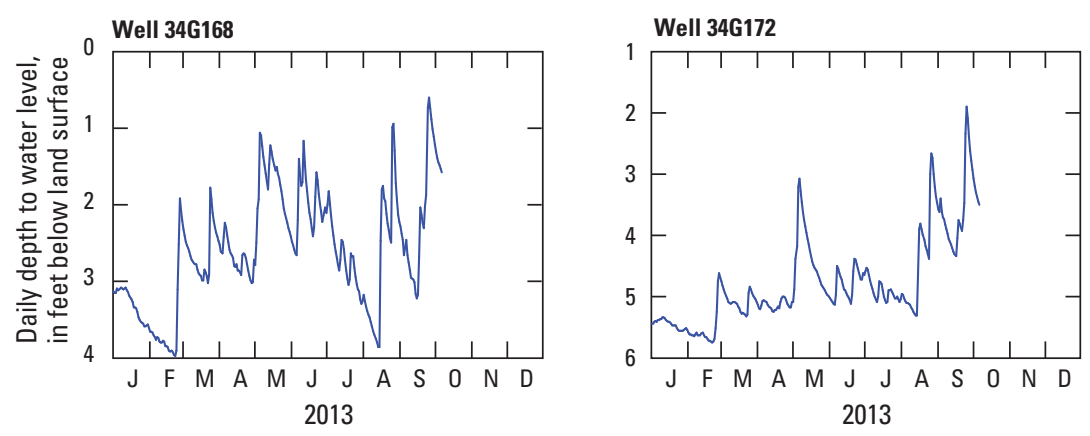

\section{Precipitation}

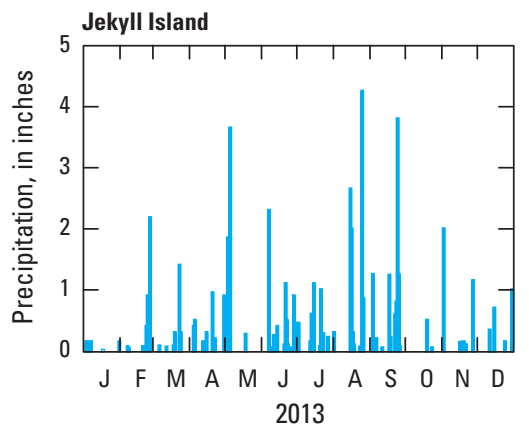

Figure 9. Groundwater levels, pond stage, and rainfall for 2013 at Jekyll Island, Georgia. 
a strong dependence of the water-table zone on recharge from precipitation to maintain the water table on Jekyll Island. Further, water-level declines resulting from low precipitation confirm the inability of the water-table zone of the surficial aquifer system to maintain the height of the water table in the absence of rainfall.

\section{Recharge}

Recharge to the water-table zone of the surficial aquifer system on Jekyll Island occurs when the amount of precipitation exceeds the cumulative effect of negative hydrologic stresses acting on the island, such as evapotranspiration, pumping, runoff to streams, storage uptake of infiltrated precipitation by the unsaturated zone (soil-moisture changes), and tidal, sea-level rise, and barometric effects. Two methods were used to estimate recharge to the water-table zone of the surficial aquifer system. Method one calculated the potential maximum recharge as a positive water balance between precipitation and evapotranspiration. Method two estimated net, or usable, recharge as volumetric differences between seasonal high and low groundwater levels.

\section{Method One-Water Balance Method}

Recharge computed with the water-balance equation 1 represents the maximum amount of unit precipitation (precipitation volume per unit area) that would infiltrate land surface and elevate the water table. Ideally, in the absence of negative hydrologic stresses other than evapotranspiration, precipitation that infiltrates land surface would represent the maximum amount of recharge available to the water-table zone of the surficial aquifer system. Other hydrologic stresses in addition to evapotranspiration, such as pumping from ponds or wells completed in the water-table zone of the surficial aquifer system, would decrease recharge from that indicated in equation 1 . Because the natural land surface and water-table zone of the surficial aquifer system of Jekyll Island is composed of permeable sand, surface-water flow, direct runoff, change in storage, and drainage through the unsaturated zone, as discussed in Healy (2010), also decreases recharge from the maximum amount given by equation 1 . All references to recharge and discharge estimates derived from equation 1 are estimates of the potential maximum recharge or precipitation excess, respectively.

Precipitation and evapotranspiration values at Brunswick, Georgia, were used in estimating recharge on Jekyll Island according to equation 1 (tables 1, 3; fig. 10). For the period October 2012-December 2013, equation 1 was used to compute monthly recharge $(R)$. Monthly water balances were obtained from the Brunswick weather station by combining monthly precipitation $(P)$ data with monthly potential evapotranspiration (ET) values (fig. 10, table 3 ). The Priestly Taylor equation was used to compute monthly potential ET from weather-station data (Matthew Evans, Electronics Engineer, The University of Georgia, Griffin, Ga.,
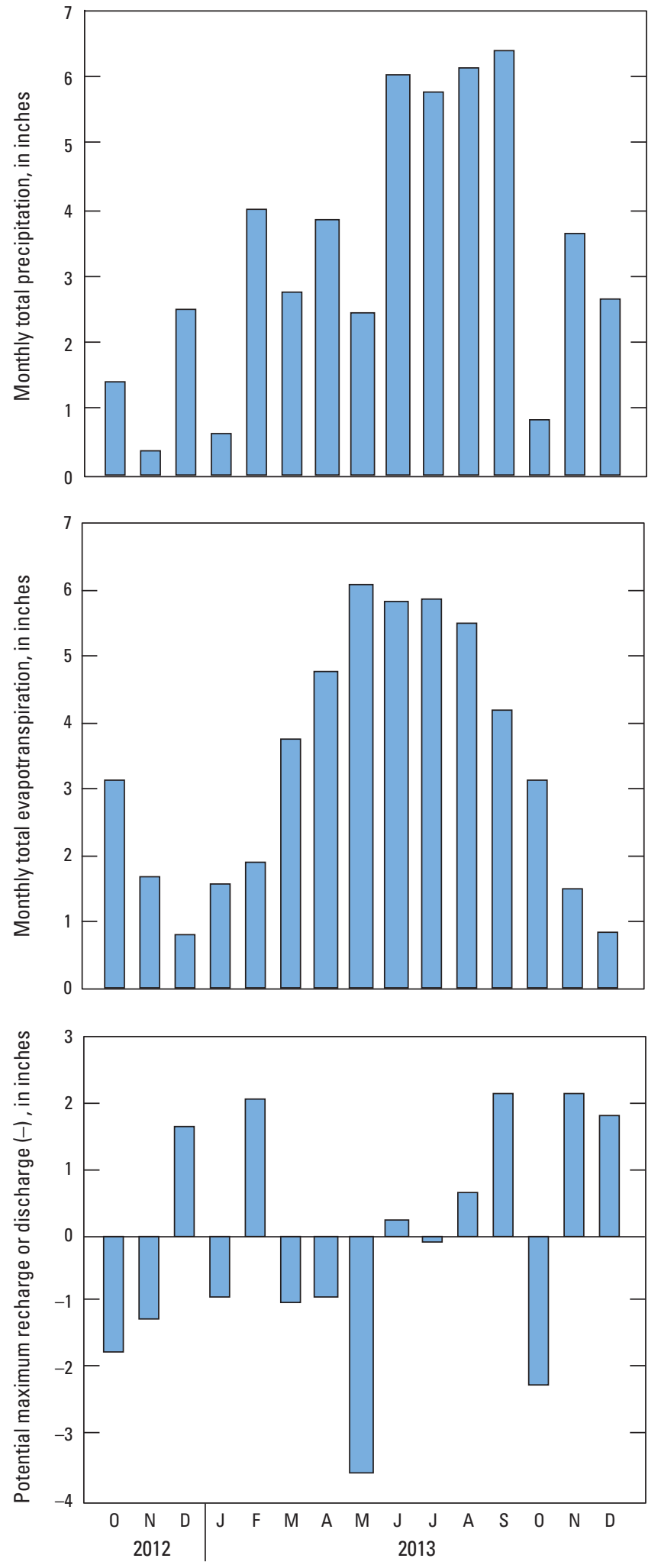

Figure 10. Monthly total $A$, precipitation, $B$, potential evapotranspiration, and $C$, water balance (potential maximum recharge) for the weather station at Brunswick, Georgia, October 2012-December 2013 (data from The University of Georgia College of Agricultural \& Environmental Sciences, 2015). 
Table 3. Monthly precipitation, evapotranspiration, and water balance (potential maximum recharge) for weather station at Brunswick, Georgia, October 2012-December 2013.

[Data from The University of Georgia College of Agricultural \& Environmental Sciences (2015). Brunswick, Georgia, $31.167^{\circ} \mathrm{N}$., $81.5^{\circ} \mathrm{W}$., altitude of 13 feet (4 meters)]

\begin{tabular}{|lccc|}
\hline \multicolumn{1}{c}{$\begin{array}{c}\text { Month and } \\
\text { year }\end{array}$} & $\begin{array}{c}\text { Precipitation } \\
\text { (inches) }\end{array}$ & $\begin{array}{c}\text { Evapo- } \\
\text { transpiration } \\
\text { (inches) }\end{array}$ & $\begin{array}{c}\text { Water } \\
\text { balance } \\
\text { (inches) }\end{array}$ \\
\hline October 2012 & 1.43 & 3.14 & -1.71 \\
\hline November 2012 & 0.39 & 1.66 & -1.28 \\
\hline December 2012 & 2.49 & 0.81 & 1.68 \\
\hline January 2013 & 0.65 & 1.58 & -0.93 \\
\hline February 2013 & 4.00 & 1.89 & 2.11 \\
\hline March 2013 & 2.77 & 3.75 & -0.99 \\
\hline April 2013 & 3.83 & 4.77 & -0.94 \\
\hline May 2013 & 2.47 & 6.07 & -3.60 \\
\hline June 2013 & 6.04 & 5.82 & 0.22 \\
\hline July 2013 & 5.76 & 5.87 & -0.11 \\
\hline August 2013 & 6.14 & 5.50 & 0.64 \\
\hline September 2013 & 6.38 & 4.20 & 2.19 \\
\hline October 2013 & 0.85 & 3.14 & -2.28 \\
\hline November 2013 & 3.63 & 1.48 & 2.15 \\
\hline December 2013 & 2.64 & 0.85 & 1.79 \\
\hline 2013 totals & $\mathbf{4 5 . 1 6}$ & $\mathbf{4 4 . 9 2}$ & $\mathbf{0 . 2 5}$ \\
\hline 2013 averages & $\mathbf{3 . 8 0}$ & $\mathbf{3 . 7 0}$ & $\mathbf{0 . 0 2 1}$ \\
\hline
\end{tabular}

written commun., April 4, 2013; Priestley and Taylor, 1972). The CRA.Clima.Evapotranspiration Web site details the Priestly Taylor potential evapotranspiration formulation (CRA-CIN, 2009).

Recharge for the period October 2012-December 2013 was calculated for Jekyll Island according to equation 1 using monthly potential evapotranspiration for the weather station at Brunswick (fig. 10) and monthly precipitation recorded at the Jekyll Island weather station (table 4).

Monthly recharge computed for Brunswick (table 3) was compared with monthly recharge estimated for the island (table 4) to identify the effects of precipitation recorded at Jekyll Island on spatial and temporal variations in recharge for the period October 2012-December 2013. Because monthly potential evapotranspiration computed for Brunswick also was used to compute monthly recharge on Jekyll Island, differences in corresponding monthly recharge estimates (fig. 11) are solely the result of differences between monthly precipitation recorded on the island and monthly precipitation recorded at Brunswick (fig. 12). Similarities in monthly recharge estimates for Jekyll Island and the monthly recharge computed for Brunswick occurred during November 2012-April 2013, and during June, and October-December 2013, when the average of monthly precipitation at the Brunswick weather station compared well with monthly precipitation on the island (figs. 11 and 12). Disparities between monthly recharge estimated for the island and that estimated for Brunswick for the remaining months of the study period, October 2012, May, and July-September 2013, are due to precipitation on Jekyll Island differing considerably from the monthly precipitation recorded at the Brunswick weather station.

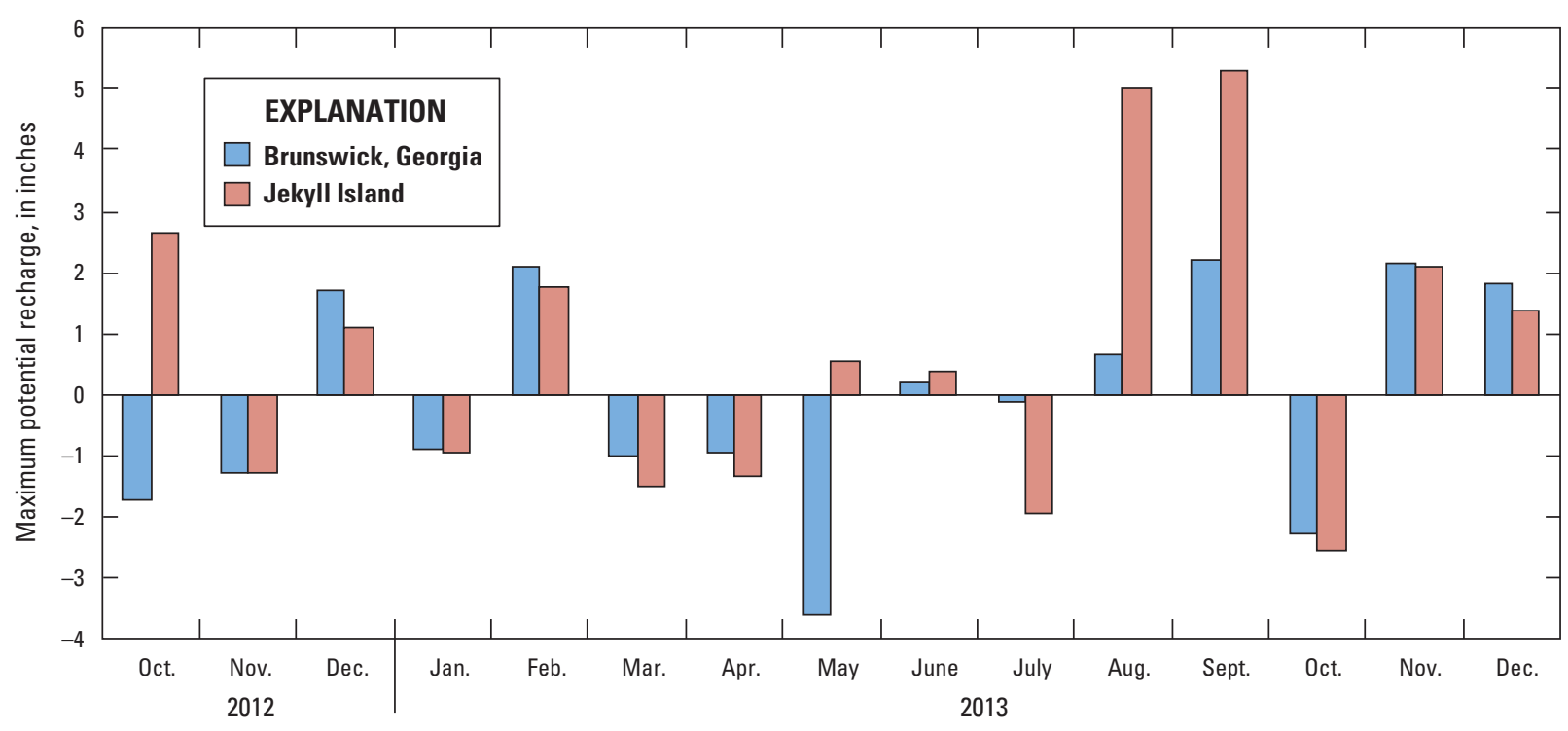

Figure 11. Monthly potential maximum recharge for Brunswick, and potential maximum recharge for Jekyll Island using evapotranspiration data from Brunswick, in inches, October 2012-December 2013 (data from The University of Georgia College of Agricultural \& Environmental Sciences, 2015). 
Table 4. Monthly potential maximum recharge or discharge for Jekyll Island estimated using precipitation from the Jekyll Island weather station and monthly evapotranspiration from the Brunswick weather station.

[Data source for evapotranspiration (ET) is The University of Georgia College of Agricultural \& Environmental Sciences (2015); Jekyll Island area $=9$ square miles $=250,905,600$ square feet $]$

\begin{tabular}{|c|c|c|c|c|c|c|}
\hline \multirow[b]{2}{*}{$\begin{array}{l}\text { Month and } \\
\text { year }\end{array}$} & \multirow{2}{*}{$\begin{array}{l}\text { Jekyll Island } \\
\text { monthly } \\
\text { precipitation } \\
\text { (inches) }\end{array}$} & \multirow{2}{*}{$\begin{array}{c}\text { 2012-13 ET from } \\
\text { Brunswick } \\
\text { weather station } \\
\text { (inches) }\end{array}$} & \multirow{2}{*}{$\begin{array}{l}\text { Maximum } \\
\text { recharge or } \\
\text { discharge (-) } \\
\text { (inches) }\end{array}$} & \multicolumn{3}{|c|}{ Potential maximum recharge or discharge (-) } \\
\hline & & & & Feet & Cubic feet & $\begin{array}{l}\text { Million } \\
\text { gallons }\end{array}$ \\
\hline October 2012 & 5.80 & 3.14 & 2.66 & 0.22 & $55,617,408$ & 416 \\
\hline November 2012 & 0.36 & 1.66 & -1.30 & -0.11 & $-27,181,440$ & -203 \\
\hline December 2012 & 1.92 & 0.81 & 1.11 & 0.09 & $23,208,768$ & 174 \\
\hline January 2013 & 0.61 & 1.58 & -0.97 & -0.08 & $-20,281,536$ & -152 \\
\hline February 2013 & 3.66 & 1.89 & 1.77 & 0.15 & $37,008,576$ & 277 \\
\hline March 2013 & 2.22 & 3.75 & -1.53 & -0.13 & $-31,990,464$ & -239 \\
\hline April 2013 & 3.40 & 4.77 & -1.37 & -0.11 & $-28,645,056$ & -214 \\
\hline May 2013 & 6.61 & 6.07 & 0.54 & 0.04 & 11290752 & 84 \\
\hline June 2013 & 6.20 & 5.82 & 0.38 & 0.03 & 7945344 & 59 \\
\hline July 2013 & 3.92 & 5.87 & -1.95 & -0.16 & -40772160 & -305 \\
\hline August 2013 & 10.51 & 5.50 & 5.01 & 0.42 & $104,753,088$ & 784 \\
\hline September 2013 & 9.48 & 4.20 & 5.28 & 0.44 & $110,398,464$ & 826 \\
\hline October 2013 & 0.55 & 3.14 & -2.59 & -0.22 & $-54,153,792$ & -405 \\
\hline November 2013 & 3.57 & 1.48 & 2.09 & 0.17 & $43,699,392$ & 327 \\
\hline December 2013 & 2.19 & 0.85 & 1.34 & 0.11 & $28,017,792$ & 210 \\
\hline Totals & 52.92 & 44.92 & 8.00 & 0.87 & $218,915,136$ & 1,638 \\
\hline Monthly averages & 4.41 & 3.70 & 0.67 & 0.06 & $14,594,342$ & 109 \\
\hline
\end{tabular}

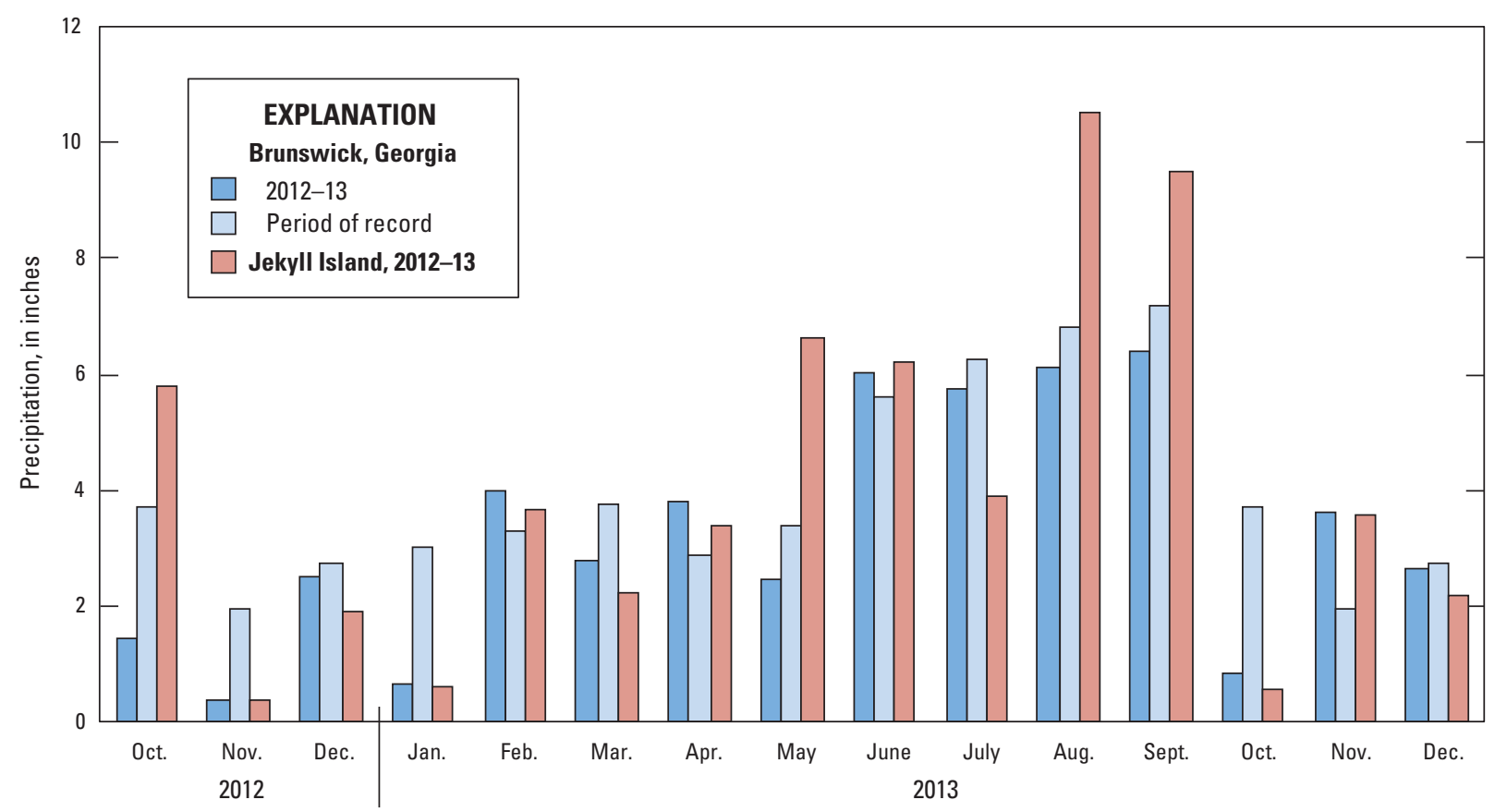

Figure 12. Monthly precipitation at Brunswick and Jekyll Island, Georgia, October 2012-December 2013, and period of record average monthly precipitation at Brunswick, Georgia (data from The University of Georgia College of Agricultural \& Environmental Sciences, 2015; Georgia Automated Environmental Monitoring Network, 2016). 
Seasonal variations in evapotranspiration caused by changes in vegetation growth, and differences in precipitation recorded on Jekyll Island from that recorded at the Brunswick weather station, affected the seasonality of recharge. Lowvegetation growth during November 2012 resulted in low evapotranspiration (table 3), which would have promoted recharge under normal (period-of-record [POR] average) precipitation conditions (fig. 12); however, low precipitation during November 2012 resulted in discharge from the water-table zone instead of recharge (fig. 11; tables 3 and 4). Conversely, above-POR-average precipitation at the two stations (tables 3 and 4) during November 2013 allowed recharge to occur in the water-table zone. Unseasonably high precipitation on Jekyll Island during October 2012, compared with POR-average precipitation at the Brunswick weather stations (fig. 12), established recharge conditions in the watertable zone on Jekyll Island for that month, although discharge conditions were produced because of below-POR-average precipitation at the Brunswick weather station (fig. 11). During the following October (2013), below-POR-average precipitation at the two weather stations (fig. 12) established discharge conditions in the water-table zone on the island and at Brunswick (fig. 11).

Seasonal-high-average evapotranspiration estimates at the Brunswick weather station during May and June 2013 (table 3) offset relatively high monthly precipitation on Jekyll Island (table 4; fig. 12) to produce less than 1 inch of recharge to the water-table zone on the island for the 2 months combined, while the Brunswick weather station posted an average discharge of about 3.6 inches during May and an average recharge of about 0.22 inch during June (fig. 11). Relatively low precipitation on Jekyll Island during July 2013 reversed slight recharge conditions on the island during the previous 2 months, resulting in almost 2 inches of discharge from the water-table zone. By comparison, average precipitation at the Brunswick weather station during July 2013 resulted in just 0.1 inch of discharge.

The most notable differences in monthly recharge on Jekyll Island, compared with the monthly recharge calculated at the Brunswick weather station, occurred during August and September 2013, and demonstrate the effect of precipitation on recharge to the water-table zone of the surficial aquifer system on the island (figs. 11 and 12; tables 3 and 4). About 20 inches of rain fell on Jekyll Island during these 2 months, resulting in more than 10 inches of recharge to the water-table zone. By comparison, about 13.2 inches of rain was recorded at the Brunswick weather station during August and September 2013 combined, resulting in about 2.8 inches of recharge during the 2-month period.

Monthly values of unit recharge, $R$ (equation 1), to the water-table zone of the surficial aquifer system on Jekyll Island translate to recharge volumes by multiplying the unit recharge by the approximate island area of about $9 \mathrm{mi}^{2}$ (table 4). Like unit recharge values computed and discussed previously, the magnitude of recharge volumes are affected by variations in precipitation and evapotranspiration. For example, the 5.8 inches of precipitation recorded on Jekyll Island during October 2012 resulted in a recharge volume of about 416 million gallons (Mgal). During October 2013, however, the 0.55 inch of precipitation that fell on the island resulted in a discharge volume from the water-table zone of about 405 Mgal. Similar comparisons of monthly precipitation establishing discharge conditions during November 2012 and recharge conditions during November 2013 indicate the importance of precipitation on recharge to, or discharge from, the water-table zone. During November 2012, 0.36 inch of precipitation produced a discharge of $203 \mathrm{Mgal}$; whereas, 3.57 inches of precipitation during November 2013 resulted in a recharge volume of $327 \mathrm{Mgal}$.

Hydrologic stresses, such as pumping from the watertable zone, uptake of infiltrating precipitation as soil moisture, surface runoff, tides, and barometric pressure variations, discussed previously, can decrease recharge (or discharge) volumes accordingly. Conversely, additional recharge may occur from lawn irrigation by homeowners who do not have private wells and so they use municipal water provided the JIA from the Upper Floridan and Brunswick aquifer systems. The combined effects of all hydrologic influences acting on the water-table zone are manifested in changes in altitude of the water table, which can be used to estimate changes in aquifer volume and net usable recharge to the water-table zone of the surficial aquifer system on Jekyll Island, as described in the following section.

\section{Method Two-Aquifer-Volume Change}

The recharge volumes in the water-table zone of the surficial aquifer system on Jekyll Island derived from method one, recharge, $R$, of equation 1 , should exceed method two, net recharge, $R_{n e t}$ computed by equation 2 because of the manner in which hydrologic stresses are considered in the computation of each recharge term. The method one recharge, $R$, is the maximum potential recharge because it takes into consideration evapotranspiration as the only hydrologic stress acting to decrease the precipitation amount available to recharge the water-table zone. By comparison, the method two recharge, $R_{n e t}$ uses the effects of all hydrologic stresses acting on the water-table zone, such as pumping from ponds or wells completed in the water-table zone of the surficial aquifer system, in addition to evapotranspiration to estimate net, or usable, recharge from aquifer-volume changes that are defined by changes in altitude of the water table. Because aquifer-volume change, $V\left(t_{2}\right)-V\left(t_{1}\right)$, in equation 2 , is based on groundwater levels that have been affected by all hydrologic stresses, the resulting value of $R_{n e t}$, would be less than the method one potential maximum recharge volume derived from $R$ in equation 1, which uses evapotranspiration as the only hydrologic stress acting on the water-table zone. 
Equation 3 was used to calculate $R_{n e t}$. Positive groundwater-level differences, $h_{\text {avg }}\left(t_{2}\right)-h_{\text {avg }}\left(t_{1}\right)$, yield positive aquifervolume change and recharge, $R_{\text {net }}$, to the water-table zone; negative groundwater-level differences indicate discharge from the water-table zone.

Estimates of net recharge, $R_{n e t}$, according to equation 3, were calculated from groundwater levels measured in wells completed in the water-table zone of the surficial aquifer system on Jekyll Island on November 8, 2012, and April 17 and August 23, 2013 (table 3-1). Results from two time periods developed from these measurements indicate that discharge of about $102 \mathrm{Mgal}$ occurred from the water-table zone during the first time period, November 8, 2012, to April 17, 2013, when discharge most likely was expected, and recharge of about $272 \mathrm{Mgal}$ occurred during the second time period, April 17 to August 23, 2013, when recharge most likely was expected (table 5), according to climate information provided by the Georgia State Climate Office (see "Climate" section). Typically in the Southeast, the combination of low evapotranspiration, and high precipitation during late fall through spring, produces recharge conditions. For Georgia's barrier island system, however, winter typically is the drier season, and other hydrologic stresses in addition to evapotranspiration have combined to produce a discharge condition in the water-table zone during the November 8, 2012, to April 17, 2013 time period, as indicated by the negative aquifer-volume change during the time period. Low precipitation on Jekyll Island during November 2012 through January 2013, paired with precipitation comparable to the POR average precipitation for the Brunswick weather station during February 2013 (fig. 12) confirm winter as a dry season and produced the discharge condition in the watertable zone during this time. Conversely, high precipitation during May and August 2013, coupled with precipitation that compared well with the POR average precipitation for the Brunswick weather station during June 2013, overcame high evapotranspiration during late-spring to mid-summer (fig. 12; table 1) to produce recharge conditions in the water-table zone during the April 17 to August 23, 2013 time period (table 5).

\section{Comparison of Recharge Calculations by Both Methods}

Comparison of recharge and discharge estimates for the water-table zone of the surficial aquifer system on Jekyll Island, calculated using method one, recharge $(R$, in equation 1) and method two, aquifer-volume change $\left(R_{n e t}\right.$ in equation 3), was difficult because the first method takes into account only monthly, total precipitation and monthly potential evapotranspiration; whereas the second method takes into account all hydrologic influences but utilizes data collected at three points in time-November 8, 2012, April 17, 2013, and August 23, 2013. Monthly average estimates of recharge or discharge volumes were calculated for both methods (tables 4 and 5). Monthly average estimates for recharge

Table 5. Average groundwater level difference, aquifer-volume change, and recharge to and discharge from the water-table zone of the surficial aquifer system, Jekyll Island, Georgia, November 8, 2012, to August 23, 2013.

[Positive values indicate net usable recharge, $R_{n e t} ;-$, not applicable]

\begin{tabular}{lcccc}
\hline \multicolumn{1}{c}{ Time period } & $\begin{array}{c}\text { Average ground- } \\
\text { water-level } \\
\text { difference } \\
\text { (in feet) }\end{array}$ & $\begin{array}{c}\text { Aquifer- } \\
\text { volume } \\
\text { change } \\
\text { (cubic feet) }\end{array}$ & $\begin{array}{c}\text { Recharge or } \\
\text { discharge (-) } \\
\text { volume } \\
\text { (cubic feet) }\end{array}$ & $\begin{array}{c}\text { Recharge or } \\
\text { discharge (-) } \\
\text { volume } \\
\text { (million gallons) }\end{array}$ \\
\hline $\begin{array}{l}\text { November 8, 2012, to } \\
\text { April 17, 2013 }\end{array}$ & -0.26 & $-65,235,456$ & $-13,699,446$ & -102 \\
$\begin{array}{l}\text { April 17 to August 23, 2013 } \\
\text { November 8, 2012, to } \\
\text { August 23, 2013 }\end{array}$ & 0.69 & $173,124,864$ & $36,356,221$ & 272 \\
\hline \multicolumn{1}{c}{ Monthly average } & 0.43 & $107,889,408$ & $22,656,776$ & 170 \\
\hline
\end{tabular}

${ }^{1}$ Average groundwater difference multiplied by area of Jekyll Island, 9 square miles $=250,905,600$ square feet, to obtain aquifer volume change, in cubic feet.

${ }^{2}$ Aquifer-volume change multiplied by porosity $(0.21)$ to obtain recharge or discharge volume, in cubic feet. 
volumes calculated using the method one, $R$, was 109 Mgal. Monthly average estimates of recharge or discharge volumes calculated using method two, $R_{\text {net }}$, was $17 \mathrm{Mgal}$.

The apparent over-estimation of $R$ by equation 1 demonstrates the inability of the simple water-balance method to account for hydrologic influences acting on the water-table zone other than evapotranspiration. These other hydrologic influences, including the existing removal of water from the surficial aquifer system via irrigation pumping, would decrease the potential maximum recharge $R$ to an actual, or net usable recharge amount, which is more closely represented by $R_{n e t}$ than $R$, as the former is derived from groundwater levels that have adjusted to all hydrologic influences acting on the water-table zone during the time that water levels were measured.

\section{Development Potential of the Water-Table Zone of the Surficial Aquifer System}

The development potential of the water-table zone in the surficial aquifer system on Jekyll Island can be inferred from the volume of water contained in the aquifer at an altitude above sea level. Groundwater levels below sea level would promote seawater encroachment to the water-table zone and degrade the freshwater resource on the island. The threat of seawater encroachment to the water-table zone of the surficial aquifer system likely will increase in the future as sea level rises (Intergovernmental Panel on Climate Change, 2013). Net recharge to the water-table zone of the surficial aquifer system can maintain the water table above sea level, prevent degradation of the freshwater supply, and allow development of the water resource. Dry climatic conditions compounded by increased pumping could decrease net recharge to the water-table zone and possibly establish discharge conditions in the water-table zone, negating any development potential previously established by net recharge conditions. Monitoring water use and maintaining groundwater-level altitudes above sea level could safeguard against discharge conditions in the water-table zone that could lead to aquifer degradation from decreased net recharge and the formation of discharge conditions.

A conservative estimate of development potential for the water-table zone in the surficial aquifer system on Jekyll Island would not only maintain groundwater-level altitudes above sea level, but would utilize only the positive groundwater-level changes during periods of net recharge. For example, the $0.69-\mathrm{ft}$ average increase in the water table during the time period from April 17 to August 23, 2013, indicates net recharge to the water-table zone and a development potential of $272 \mathrm{Mgal}$ (table 5). In other words, $272 \mathrm{Mgal}$ could have been withdrawn from the water-table zone during this period at the expense of utilizing only the 0.69 -ft average increase in groundwater levels on the island. Theoretically, at the end of the time period on August 23, 2013, the configuration of the water table would be identical to the configuration on April 17, 2013 (fig. 8B), because only the net recharge to the water-table zone gained during the time period was developed for use.

A negative development potential for the water-table zone in the surficial aquifer system occurs when discharge conditions exist on Jekyll Island. For example, the discharge of $102 \mathrm{Mgal}$ from the water-table zone inferred from groundwater levels measured on November 8, 2012, and April 17, 2013, resulted in an average water-table decline of $0.26 \mathrm{ft}$ on the island (table 5). Additional negative hydrologic stresses in excess of $102 \mathrm{Mgal}$, such as from increased pumping, would further lower the water table from the level already exhibited during the period.

Antecedent recharge or discharge conditions could be used to determine the development potential in the water-table zone of the surficial aquifer system on Jekyll Island. Increases in the water table during recharge conditions could be reserved for development of water resources during a future discharge condition. The converse situation of developing water resources, and incurring subsequent lowering of the water table, during periods of net discharge in anticipation of future recharge conditions could have negative and deleterious consequences on the water-table aquifer if prolonged discharge conditions could not be offset by watertable increases during a future, net-recharge condition. In this example, the freshwater of the water-table zone would be threatened by excessive water-level declines that could extend below sea level, promoting seawater encroachment. Consider the following hypothetical example based on groundwater levels measured during the period of November 8, 2012, to August 23, 2013. The net-average increase in the water table on Jekyll Island of $0.43 \mathrm{ft}$ indicated by groundwater-level measurements for this time period (table 5) implies that if recharge was predicted to occur with the magnitude indicated by groundwater-level measurements during the wet period of April 17 to August 23, 2013, then the expected gain in water resources given by this recharge condition could have been utilized during the preceding dry (discharge) period of November 8, 2012, to April 17, 2013. The net-recharge condition that occurred during the wet period of April 17 to August 23, 2013 was uncertain, however, and increased development of water resources during the preceding discharge period by this amount $(0.43 \mathrm{ft}$, or 170 million gallons per day [Mgal/d], table 5) may not have been offset by the future recharge condition. The period of record average precipitation and evapotranspiration at Brunswick, Georgia, suggests that in a typical year the water level would increase by about 12 inches (table 1). 


\section{Baseline Groundwater Quality}

To assess the usability of the water resource and to corroborate estimations of flow direction inferred from water-table elevations, samples were collected to establish baseline groundwater-quality conditions. The samples were collected on August 23, 2013, from six wells installed during this study as part of the 26-well monitoring network (fig. 1B). Water-quality analyses yielded values for alkalinity, hardness, $\mathrm{pH}$, specific conductance, total dissolved solids (TDS), and chloride concentration (table 2) that can be used as a basis for comparison during future investigations. In addition, field measurements of specific conductance and temperature were taken in water samples collected from 89 existing residential wells assumed to be completed in the water-table zone of the surficial aquifer system. A map showing well locations and specific-conductance values for selected residential wells (fig. 1-1) and a table showing SC and temperature data for the 89 residential wells (table $1-1$ ) is provided in appendix 1.

Specific conductance was measured in water samples from the 26-well network during November 2012, April 2013, and August 2013 to identify spatial and temporal variations that could indicate similar variations in chloride concentration related to groundwater-flow directions in the water-table zone of the surficial aquifer system on Jekyll Island (fig. 13, table 6). Variations in specific conductance at well 34G157, located adjacent to the marshland on the west side of the island, indicated relatively low specific conductance (605 $\mu \mathrm{S} / \mathrm{cm})$ during the November 2012 sampling period (fig. 13A), when groundwater flowed westward from an apparent recharge area in the central part of the island toward the marshland (fig. 8A). In contrast, during April 2013, groundwater flowed from the marshland eastward past the same well and toward a swampy area in the central part of the island (fig. 8B). Commensurate with this change in groundwater-flow direction, which seemingly transported relatively high saline water into the water-table zone, is a relatively high specific conductance of $2,268 \mu \mathrm{S} / \mathrm{cm}$ measured in a water sample at well 34G157 during April 2013 (fig. 13B, table 6). As the groundwater-flow direction again shifted westward in this area during August 2013, specific conductance in water sampled at well $35 \mathrm{G} 157$ decreased to $1,618 \mu \mathrm{S} / \mathrm{cm}$, indicating a replenishment of the water-table zone with freshwater from the central part of the island between April and August 2013 (compare figs. $8 B$ and $8 C$ for groundwater-flow directions, and figs. $13 B$ and $13 C$ for specific conductance values).

Similar relations between specific conductance (and chloride concentration) and groundwater-flow directions inferred at well 34G157 also can be inferred at well 34G161 (figs. 8 and 13, table 6). Specific conductance from water samples taken at this well indicate fairly constant waterquality conditions, with SC values increasing slightly from $549 \mu \mathrm{S} / \mathrm{cm}$ during November 2012 to $657 \mu \mathrm{S} / \mathrm{cm}$ during April 2013. Groundwater-flow directions during these sampling periods indicate that freshwater recharging the water-table zone near a pond in the central part of the island was flowing southward past well 34G161. In comparison, the recharge area to the north of the well that was established during November 2012 and April 2013 seems less defined during August 2013, which might have allowed saline water from the marshland to the northwest of the well to infiltrate the water-table zone, as indicated by a specific conductance value of $1,507 \mu \mathrm{S} / \mathrm{cm}$ measured in a water sample taken at this well during August 2013. 


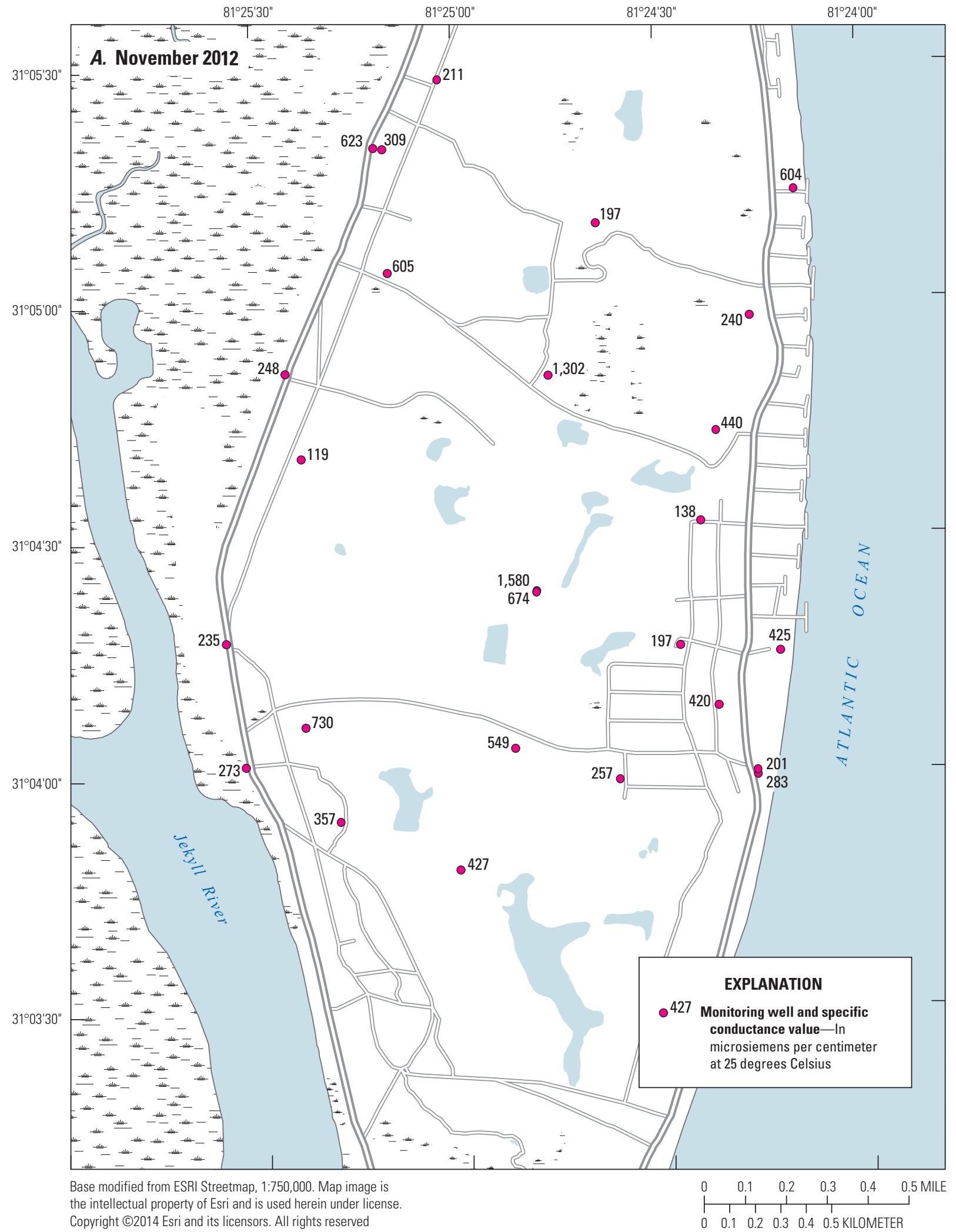

Figure 13. Distribution of specific conductance during, $A$, November 2012, B, April 2013, and $C$, August 2013 in 26 wells on Jekyll Island, Georgia. 


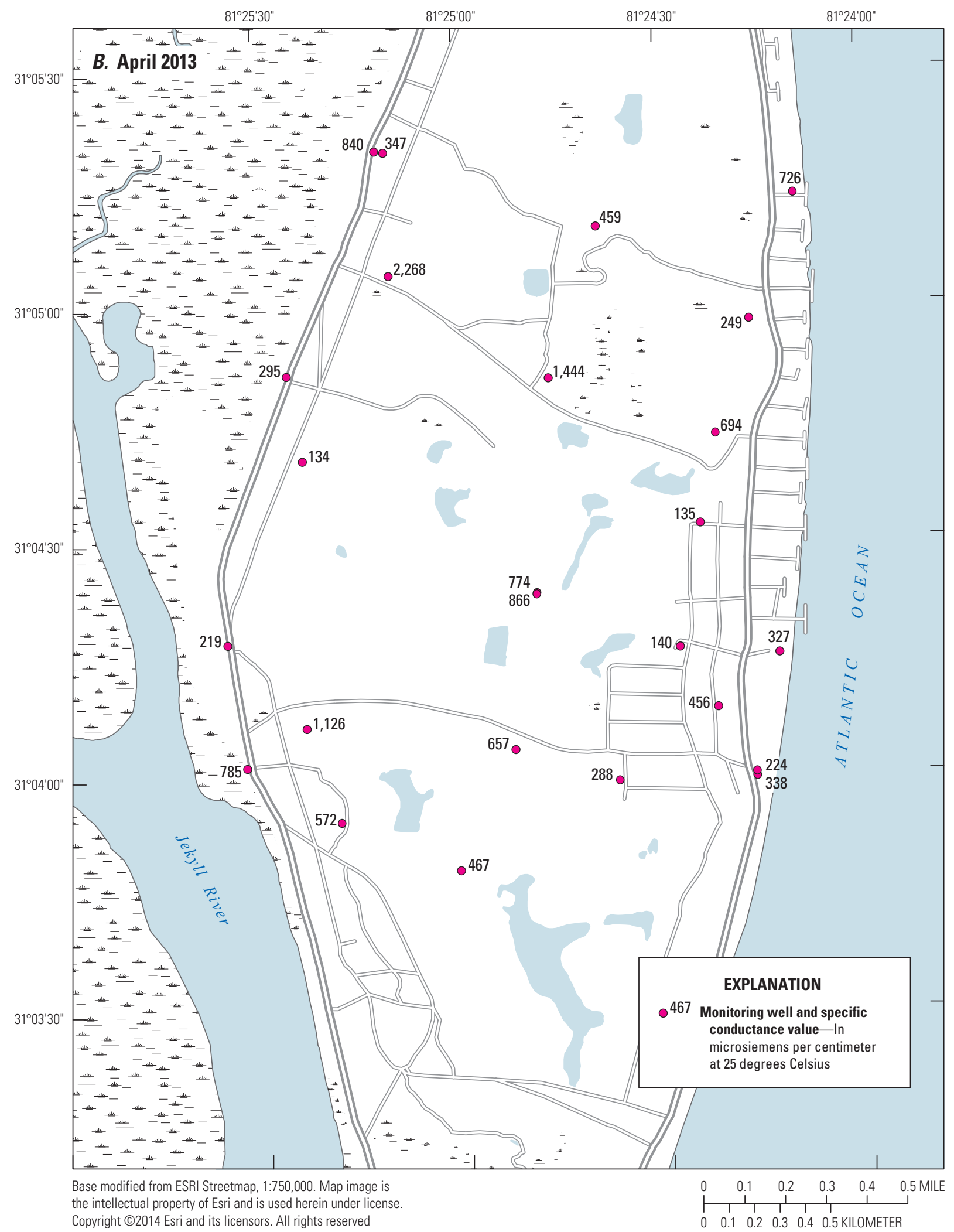

Figure 13. Distribution of specific conductance during, A, November 2012, B, April 2013, and C, August 2013 in 26 wells on Jekyll Island, Georgia. 


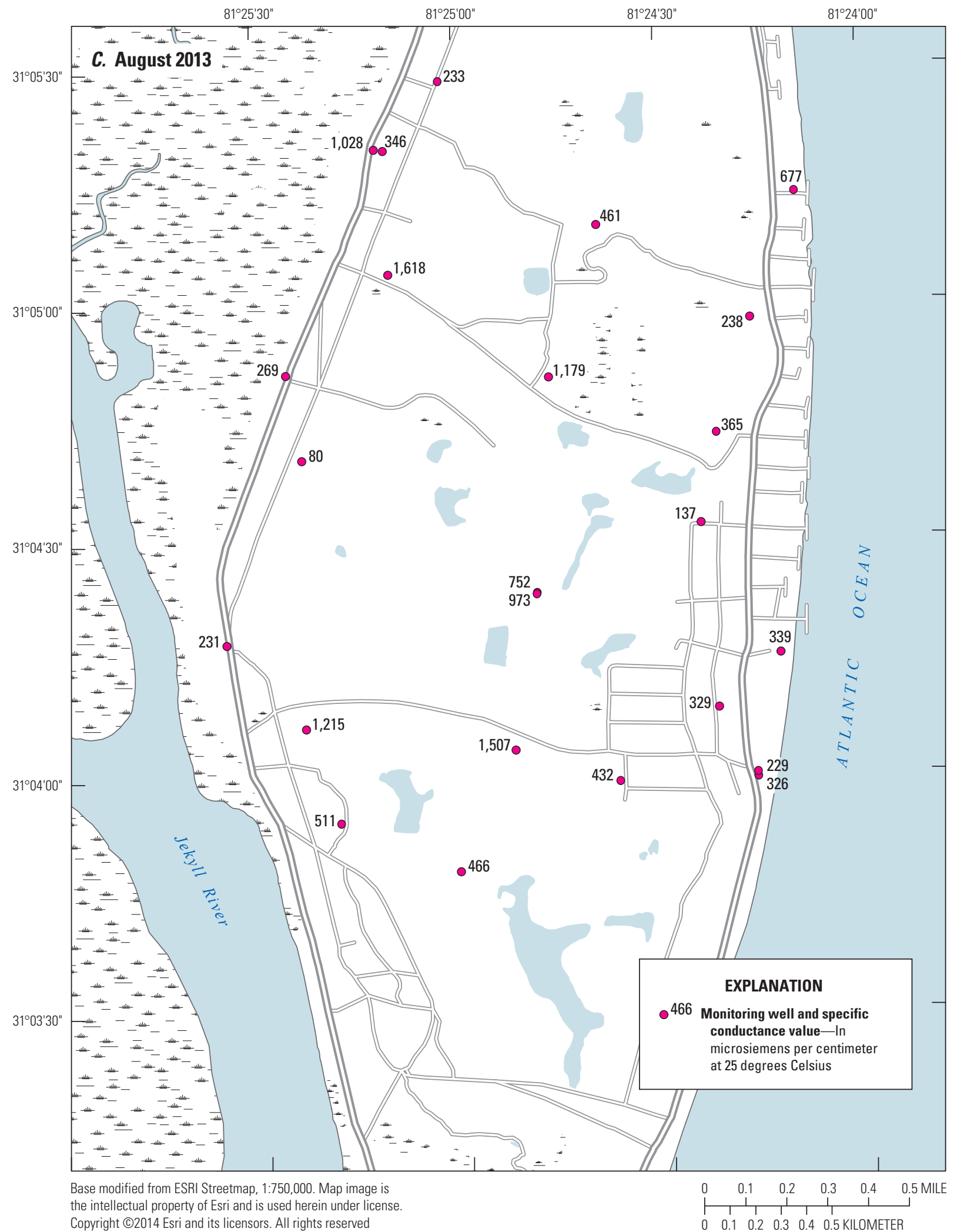

Figure 13. Distribution of specific conductance during, $A$, November 2012, B, April 2013, and $C$, August 2013 in 26 wells on Jekyll Island, Georgia. 
Table 6. Specific conductance values collected from newly constructed wells, Jekyll Island, Georgia, November and December 2012, April and August 2013.

$\left[\mu \mathrm{S} / \mathrm{cm}\right.$ at $25^{\circ} \mathrm{C}$, microsiemens per centimeter at 25 degrees Celsius; values shown in red are samples with chloride concentrations that exceed Federal and State secondary drinking-water standards. The standard for chloride concentration is 250 milligrams per liter (Georgia Environmental Protection Division, 1997; U.S. Environmental Protection Agency, 2000), which corresponds to a specific conductance value of $1,000 \mu \mathrm{S} / \mathrm{cm}$ at $25^{\circ} \mathrm{C}$; - , no data]

\begin{tabular}{|c|c|c|c|c|c|}
\hline \multirow{2}{*}{$\begin{array}{c}\text { USGS } \\
\text { well } \\
\text { identifier }\end{array}$} & \multirow{2}{*}{$\begin{array}{l}\text { Well depth below } \\
\text { land surface } \\
\text { (feet) }\end{array}$} & \multicolumn{4}{|c|}{ Specific conductance $\left(\mu \mathrm{S} / \mathrm{cm}\right.$ at $\left.25^{\circ} \mathrm{C}\right)$} \\
\hline & & November 2012 & December 2012 & April 2013 & August 2013 \\
\hline $34 \mathrm{G} 150$ & 18.1 & 197 & 178 & 140 & - \\
\hline $34 \mathrm{G} 151$ & 11.2 & 240 & 228 & 249 & 238 \\
\hline $34 \mathrm{G} 152$ & 13.0 & 357 & 403 & 572 & 511 \\
\hline $34 \mathrm{G} 153$ & 10.0 & 273 & 311 & 785 & - \\
\hline $34 \mathrm{G} 154$ & 19.6 & 730 & 910 & 1,126 & 1,215 \\
\hline $34 \mathrm{G} 155$ & 15.5 & 235 & 239 & 219 & 231 \\
\hline $34 \mathrm{G} 156$ & 9.4 & 119 & 124 & 134 & 80 \\
\hline $34 \mathrm{G} 157$ & 19.4 & 605 & 614 & 2,268 & 1,618 \\
\hline $34 \mathrm{G} 158$ & 12.8 & 1,302 & 1,327 & 1,444 & 1,179 \\
\hline $34 \mathrm{G} 159$ & 12.5 & 604 & 774 & 726 & 677 \\
\hline $34 \mathrm{G} 160$ & 11.6 & 440 & 560 & 694 & 365 \\
\hline $34 \mathrm{G} 161$ & 12.2 & 549 & 580 & 657 & 1,507 \\
\hline $34 \mathrm{G} 162$ & 10.9 & 420 & 721 & 456 & 329 \\
\hline $34 \mathrm{G} 163$ & 10.8 & 138 & 177 & 135 & 137 \\
\hline $34 \mathrm{G} 164$ & 24.3 & 425 & 420 & 327 & 339 \\
\hline $34 \mathrm{G} 165$ & 19.6 & 201 & 217 & 224 & 229 \\
\hline $34 \mathrm{G} 166$ & 11.8 & 427 & 467 & 467 & 466 \\
\hline $34 \mathrm{G} 167$ & 15.3 & 248 & 336 & 295 & 269 \\
\hline $34 \mathrm{G} 168$ & 18.8 & 309 & 295 & 347 & 346 \\
\hline $34 \mathrm{G} 169$ & 19.4 & 211 & 201 & 170 & 233 \\
\hline $34 \mathrm{G} 170$ & 27.9 & 197 & 481 & 459 & 461 \\
\hline $34 \mathrm{G} 171$ & 14.0 & 257 & 288 & 288 & 432 \\
\hline $34 \mathrm{G} 172$ & 29.0 & 1,580 & 758 & 774 & 752 \\
\hline $34 \mathrm{G} 173$ & 7.4 & 674 & 1,020 & 866 & 973 \\
\hline $34 \mathrm{G} 174$ & 7.4 & 623 & 737 & 840 & 1,028 \\
\hline $34 \mathrm{G} 175$ & 7.8 & 283 & 339 & 338 & 326 \\
\hline
\end{tabular}




\section{Summary and Conclusions}

Jekyll Island is part of Georgia's barrier island system formed with a hydrogeologic framework that established freshwater resources in a water-table zone of the surficial aquifer system which, like the entire island, is composed of marine beach sands and reworked mainland sediments. Infiltration of rainfall is a major provider of freshwater recharge to the island and is more than adequate to support a water-table zone in the surficial aquifer system that holds back seawater encroachment, at current hydrologic conditions, by maintaining groundwater levels above sea level in the island sediments.

Precipitation varies both seasonally and geographically more than evapotranspiration on and adjacent to Jekyll Island. While evapotranspiration continues at seasonal rates and is minimally affected by dry or wet climatic conditions, precipitation affects recharge to the water-table zone of the surficial aquifer system, causing seasonal reversals of recharge-todischarge conditions, or vice versa, with unseasonably low or high rainfall. Most of the weekly and continuously measured wells exhibited a water-level increase of about 5 inches by the end of 2013, thus indicating that the surficial aquifer system was being recharged during the study period. The period of record average precipitation and evapotranspiration at Brunswick, Georgia, suggests that in a typical year the water level would increase by about 12 inches.

Development potential of freshwater resources in the water-table zone of the surficial aquifer system on Jekyll Island hinges on the ability to maintain groundwater-level altitudes above sea level. Careful balancing of the natural and man-made hydrologic stresses acting on the water-table zone will determine whether groundwater-level altitudes will support a freshwater resource in a water table situated above sea level, or whether the combination of negative hydrologic stresses, such as evapotranspiration and groundwater pumping, will lower the water table below sea level, promoting seawater encroachment and degradation of the freshwater resource on the island. Because the configuration of the water table is a manifestation of all hydrologic influences acting on the watertable zone at a given time, monitoring groundwater levels, water use, and water quality could help identify potential seawater-encroachment conditions. Managing freshwater recharge to the water-table zone from infiltration of precipitation, and mitigating discharge conditions in the water-table zone by limiting pumping, is essential to maintain the water table above sea level and to preserve the development potential and freshwater resources on the island.

The response of the water table to precipitation demonstrated by groundwater levels in wells completed in the water-table zone on Jekyll island indicates that the barrier island sediments of the surficial aquifer system can drain and transmit water equally well in multiple directions. Although this is a desirable characteristic for an aquifer to possess, the water-table zone of the surficial aquifer system is vulnerable to depletion from overpumping of wells installed in this hydrogeologic unit or from prolonged or extreme dry climatic conditions under current pumping rates or potential increases in mean sea level. The water table cannot be maintained at a given height unless it receives recharge from precipitation at a rate that equals or exceeds the combined stresses of evapotranspiration, pumping, overland runoff, groundwater flow to ponds, soil-moisture uptake, tides, barometric pressure changes, and sea-level rise. Failure to maintain the water table at a height above sea level will induce seawater to encroach into the water-table zone of the surficial aquifer system and increase the salinity of water in the water-table zone decreasing its utility as a resource. The threat of seawater encroachment to the water-table zone of the surficial aquifer system likely will increase in the future as sea level rises.

The current distribution of 26 wells installed during this study in the water-table zone of the surficial aquifer system on Jekyll Island, coupled with three pond staff gages, constitutes a data-collection network from which groundwater-level and water-quality conditions can be monitored for future evaluation of freshwater resources. Although the Brunswick weather station provided useful evapotranspiration values for calculating potential maximum recharge, a weather station on Jekyll Island that measures meteorological conditions needed to compute evapotranspiration on the island would enhance the certainty of recharge calculations and contribute toward understanding the hydrology of Jekyll Island and of Georgia's barrier island system in general. Water applied as irrigation was considered consumptive for this study. Further study is needed to determine if this water is fully consumptive or to some degree contributes to recharge. 


\section{Selected References}

AECOM, 2011, Jekyll Island Conservation Plan: AECOM, Orlando, Florida, 80 p., accessed December 3, 2014, at http://issuu.com/jekyllisland/docs/9-25conservation_plan_ combined $/ 1 ? \mathrm{e}=6212058 / 7823870$.

Arbogast, A.F., 2014, Maritime vs. continental effect, in Discovering physical geography ( $3 \mathrm{~d}$ ed): John Wiley \& Sons, accessed March 26, 2015, at http://www.wiley.com/ college/arbogast/047143860X/geo_interactions/ch05/ maritime_continental_effect/index.htm. [Online animation/ module to accompany text.]

Buddemeier, R.W. and Schloss, J.A., 2000, Groundwater Storage and Flow, Web site accessed September 29, 2015, http://www.kgs.ku.edu/HighPlains/atlas/apgengw.htm.

Cherry, G.S., Peck, M.F., Painter, J.A., and Stayton, W.L., 2010, Groundwater conditions and studies in the BrunswickGlynn County area, Georgia, 2008: U.S. Geological Survey Open-File Report 2009-1275, 54 p., accessed January 18, 2011, at http:/pubs.usgs.gov/of/2009/1275/.

Cherry, G.S., Peck, M.F., Painter, J.A., and Stayton, W.L., 2011, Groundwater conditions in the Brunswick-Glynn County area, Georgia, 2009: U.S. Geological Survey Scientific Investigations Report 2011-5087, 58 p.

Chowns, T.M., Schultz, B.S., Griffin, J.R., and Crook, M.R., Jr., 2008, Relocation of Brunswick River and other estuaries on the Georgia, USA coast as a consequence of Holocene transgression: Southeastern Geology, v. 45, no. 3, p. 143-159.

Clark, W.Z., and Zisa, A.C., 1976, Physiographic map of Georgia: Georgia Geological Survey, 1 sheet, scale 1:2,000,000.Clarke, J.S., 2003, The Surficial and Brunswick aquifer systems - Alternative groundwater resources for Coastal Georgia, in Hatcher, K.J., ed., Proceedings of the 2003 Georgia Water Resources Conference, held April 23-24, 2003, at the University of Georgia. Institute of Ecology: The University of Georgia, Athens, Georgia.

Clarke, J.S., Hacke, C.M., and Peck, M.F., 1990, Geology and ground-water resources of the coastal area of Georgia: Georgia Geologic Survey Information Circular 113, 106 p.

Clarke, J.S., and Krause, R.E., 2000, Design, revision, and application of ground-water flow models for simulation of selected water-management scenarios in the coastal area of Georgia and adjacent parts of South Carolina and Florida: U.S. Geological Survey Water-Resources Investigations Report 00-4084, 93 p.

CRA-CIN, 2009, Priestley-Taylor equation: CRA.Clima. Evapotranspiration Web site accessed April 2, 2015, at http://agsys.cra-cin.it/tools/evapotranspiration/ help/Priestley-Taylor.html.
Dilsaver, L.M., 2004, Cumberland Island National Seashore: a history of conservation conflict: Charlottesville, Va., University of Virginia Press, 323 p.

Fetter, C.W., 2001, Applied hydrogeology (4th ed.): Upper Saddle River, N.J., Prentice-Hall, 598 p.

Georgia Automated Environmental Monitoring Network, 2016, College of Coastal Georgia-Brunswick, Glynn County, Georgia: Georgia Automated Environmental Monitoring Network Web site accessed February 22, 2016, at http://www.georgiaweather.net/index.php?content= gp\&site=BRUNSW.

Georgia Environmental Protection Division, 1997, Secondary Maximum Contaminant Levels for drinking waterEnvironmental Rule 391-3-5-19, revised October 1997: Official Code of Georgia Annotated Statutes, Statute 12-5-170 (Georgia Safe Drinking Water Act) [variously paged].

Healy, R.W., 2010, Estimating groundwater recharge: United Kingdom, Cambridge University Press, 245 p.

Henry, V.J., 2014, Geology of the Georgia Coast in New Georgia Encyclopedia: Georgia Humanities Council and the University of Georgia Press, accessed March 19, 2015, at http://www.georgiaencyclopedia.org/articles/sciencemedicine/geology-georgia-coast.

Intergovernmental Panel on Climate Change, 2013, Summary for policymakers, in Climate Change 2013 - The physical science basis, Contribution of Working Group I to the fifth assessment report of the Intergovernmental Panel on Climate Change [T.F. Stocker, D. Qin, G.-K. Plattner, M. Tignor, S.K. Allen, J. Boschung, A. Nauels, Y. Xia, V. Bex and P.M. Midgley, eds.]: Cambridge, U.K., and New York, Cambridge University Press, p. 1-30, accessed January 12, 2016, at http://dx.doi.org/10.1017/CBO9781107415324.004.

Jekyll Island Authority, 2011a, Jekyll Island Conservation Plan Part 1: AECOM, Orlando, FL, 39 p.

Jekyll Island Authority, 2011b, Jekyll Island Conservation Plan Part 2: AECOM, Orlando, FL, 79 p.

Leeth, D.C., 1999, Hydrogeology of the surficial aquifer in the vicinity of a former landfill, Naval Submarine Base Kings Bay, Camden County, Georgia: U.S. Geological Survey Water-Resources Investigations Report 98-4246, 28 p.

Media Insights.com [2014], Jekyll Island Weather, accessed April 4, 2014, and March 18, 2015 at http:/www.jekyll island.org/Weather.html.

Priestley, C.H.B., and Taylor, R.J., 1972: On the assessment of surface heat flux and evaporation using large-scale parameters: Monthly Weather Review, v. 100, p. 81-92, http://dx.doi.org/10.1175/1520-0493(1972)100<0081: OTAOSH>2.3.CO;2. 
Randolph, R.B., Pernik, Maribeth, and Garza, Regina, 1991, Water-supply potential of the Floridan aquifer system in the coastal area of Georgia-A digital model approach: Georgia Geologic Survey Bulletin 116, 30 p.

The University of Georgia College of Agricultural \& Environmental Sciences, 2015, Georgia Climate Information: GaClimate.org Web site accessed March 19, 2015, at http://www.gaclimate.com.

The University of Georgia, Georgia State Climate Office, Driftmier Engineering Center, 1998, Climatology of the Georgia coastal plain: Accessed March 18, 2015, at http://coastgis.marsci.uga.edu/summit/_notes/coastal.pdf.

University of Illinois, 2010, Effects of cloud cover: WW2010 Web site accessed April 2, 2015, at http://ww2010.atmos. uiuc.edu/(Gh)/guides/mtr/fcst/tmps/cld.rxml.

U.S. Census Bureau, 2012: U.S. Census Bureau data: U.S. Census Bureau Web site accessed March 18, 2015, at https://www.census.gov/ compendia/statab/2012/ tables/12s0364.pdf.
U.S. Environmental Protection Agency, 2000 (revised), Maximum Contaminant Levels (Part 143, National Secondary Drinking-Water Regulations): U.S. Code of Federal Regulations, Title 40, parts 100-149.

U.S. Environmental Protection Agency [2014?], Outdoor water use in the United States: Water Sense Web page, accessed April 1, 2014, at http://www.epa.gov/watersense/ pubs/outdoor.html.

U.S. Geological Survey, [2014], Geolex-Significant Publications: National Geologic Map Database accessed September 19, 2014, at http://ngmdb.usgs.gov/Geolex/ UnitRefs/MarksHeadRefs_2647.html.

Watson, T.W., 1982, Aquifer potential of the shallow sediments of the coastal area of Georgia, in Proceedings of the second symposium on the Geology of the southeastern coastal plain: Georgia Geologic Survey Information Circular 53, p. 191.

Weems, R.E., and Edwards, L.E., 2001, Geology of Oligocene, Miocene, and younger deposits in the coastal area of Georgia: Georgia Geologic Survey Bulletin 131, 124 p. 


\section{Appendix 1. Wells Inventoried for This Study}

Table 1-1 showing the location of existing wells inventoried and specific conductance and temperature data collected, Jekyll Island, Georgia, is available online at http://dx.doi.org/10.3133/ofr20161017. 


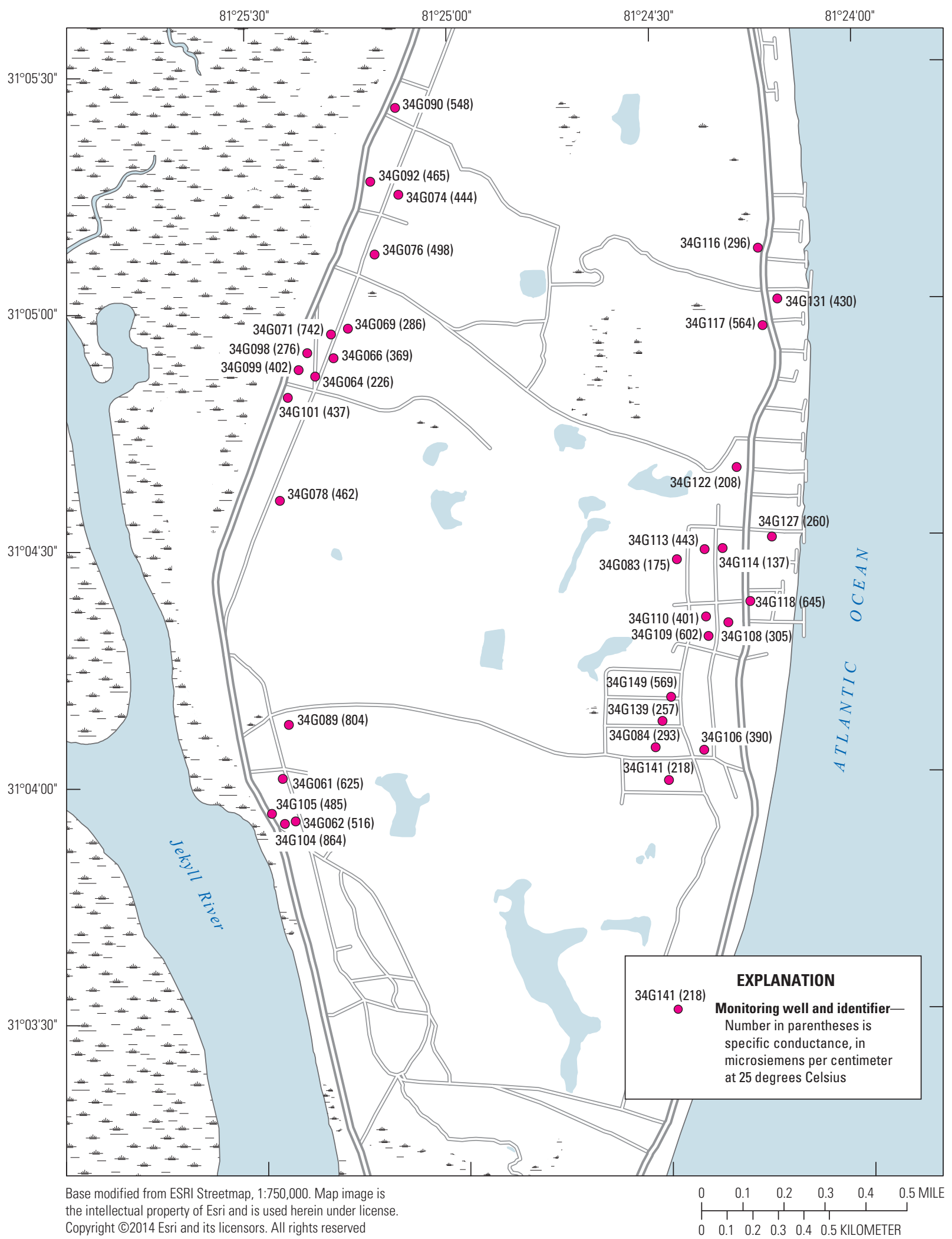

Figure 1-1. Location of, and specific conductance measured in, private wells inventoried for this study, Jekyll Island, Georgia, 2012. 


\section{Appendix 2. Construction of Monitoring Wells}

Twenty-six shallow monitoring wells were installed to more accurately characterize the water-table zone of the surficial aquifer system than previously defined with the distribution of existing wells (fig. $1 B$ ). These wells include three cluster sites where two adjacent wells were installed at different depths to provide information about local vertical hydraulic gradients and waterquality variations within the surficial aquifer system. The wells range in depth from 7.4 to $29.1 \mathrm{ft}$ below land surface and were constructed using schedule 40, 2-inch-diameter PVC pipe with screens lengths of $5 \mathrm{ft}$ and a slot size of 0.01 inch (table 2-1). The monitoring wells were used to collect water-level data and to measure specific conductance. Lithologic samples were collected during well construction and used to characterize the soil type and geology.

Two USGS-constructed wells were equipped with continuous recorders-well 34G172, located in an upland recharge area in the center of the island and well $34 \mathrm{G168}$, located in a lowland discharge area in the northwestern part of the island.

Table 2-1 showing well construction information for monitoring wells installed for this study, Jekyll Island, Georgia, is available online at http://dx.doi.org/10.3133/ofr20161017.

\section{Appendix 3. Groundwater-Level Measurements Made on November 8, 2012, April 17, 2013, and August 23, 2013}

Table 3-1 showing groundwater levels measured on Jekyll Island, Georgia, November 8, 2012, April 17 and August 23, 2013, is available online at http://dx.doi.org/10.3133/ofr20161017. 
Manuscript approved on February 11, 2016

Prepared by the USGS Science Publishing Network Raleigh Publishing Service Center

Edited by Michael Deacon

Illustrations and layout by Caryl J. Wipperfurth

For more information about this publication contact: Director, South Atlantic Water Science Center U.S. Geological Survey

720 Gracern Road

Columbia, SC 29210

http://www.usgs.gov/water/southatlantic/ 
